\title{
What Will It Take to Label Participation in a Deceptive Scheme to Defraud Buyers of Securities a Violation of Section 10(b)? The Disastrous Result and Reasoning of Stoneridge
}

Mark Klock*

\section{INTRODUCTION}

Once again, the United States Supreme Court has passed on a ripe opportunity to facilitate Congress's intent to protect the integrity of our public securities markets under the Securities Exchange Act of 1934 ("1934 Act") and instead has chosen to frustrate both sound policy and statutory language with feeble legal analysis in Stoneridge Investment Partners, LLC v. Scientific-Atlanta, Inc. ${ }^{1} \quad$ In holding in favor of defendants who actively aided and participated in inflating revenues and hiding costs used to prepare public financial statements, ${ }^{2}$ the Court continued its more than two-decade-old hostility towards our system of protecting the integrity of securities markets with private causes of action for fraud. ${ }^{3}$ Stoneridge continues the pattern in Gustafson v. Alloyd Co. ${ }^{4}$ and Central Bank of Denver v. First Interstate Bank of Denver ${ }^{5}$ of insulating culpable parties from private action liability when they did not directly participate in the sale of securities. ${ }^{6}$ In Stoneridge, the Supreme

\footnotetext{
* $\quad$ B.A., The Pennsylvania State University, 1978; Ph.D. in Economics, Boston College, 1983; J.D. (with honors), University of Maryland, 1988; admitted to the Maryland Bar, 1988; admitted to the District of Columbia Bar, 1989; Professor of Finance, The George Washington University, Washington, D.C.

1. 128 S. Ct. 761 (2008).

2. Id. at $766-67$.

3. Cf. id. at 779 (Stevens, J., dissenting) ("A theme that underlies the Court's analysis is its mistaken hostility towards the $\S 10(\mathrm{~b})$ private cause of action.").

4. 513 U.S. 561 (1995).

5. 511 U.S. 164 (1994).

6. See Stuart Sinai, Stoneridge-Escape From Securities Liability Notwithstanding Active, Intentional, Deceptive Conduct, 8 J. BUS. \& SEC. L. 170, 187 (2008). Mr. Sinai fairly concludes: Under Stoneridge, a professional can rest easy so long as the attorney, CPA, and investment banker make no statements to the public. It appears no matter their culpability, they will escape private civil liability under $\S 10(\mathrm{~b})$. As mere "aiders and abettors," Stoneridge excludes them from coverage under $\S 10(\mathrm{~b})$ and the Rule. The
} 
Court went even further than it had before and found that corporations who knowingly and actively participated in a scheme to create phony revenue and fool the auditors certifying publicly filed financial statements are beyond the reach of federal securities laws. ${ }^{7}$ The reasoning underlying such a bizarre conclusion was that the fraud was consummated in the market for goods and services rather than the securities market. ${ }^{8}$

Hence, I ask the question in the title: what will it take to label such conduct as participation in a deceptive scheme to defraud buyers or sellers of securities? With this Court, it is clear that no unethical conduct by corporations assisting securities fraud will be actionable by the victims as long as the corporation avoids direct communication with the victims. $^{9}$ As part of the solution to the drastic loss of confidence in U.S. markets which we are experiencing now, ${ }^{10}$ the President and Congress must expressly direct the Court, through legislation, to allow private actions against secondary participants. Again, what will it take to wake up those who are steering the economy and the legal system?

Perhaps the answer to the question posed by this paper is: $n$ (Bernie Madoffs). I do not know the value of $n$, but surely there exists a number of fifty-billion-dollar-Ponzi-schemes which will motivate the President and Congress to intervene and provide the leadership the Supreme Court has failed to provide in protecting the integrity of our financial markets.

I argue that the Court decided Stoneridge incorrectly because the majority over-simplified the concepts of causation, reliance, and duty. I also argue that the unintended consequence of the Court's decision will be to drive controversies over securities fraud into state courts where they can be litigated as a breach of fiduciary duty under what is generally more expansive corporate law rather than litigating these cases under our

lawyer that works, plans and schemes with his client to deceive and defraud the investing public, but who is careful to make no public statements, is free of civil liability under the

Eighth Circuit's and Supreme Court's current view as expressed in Stoneridge. Id.

7. Stoneridge, 128 S. Ct. at 774.

8. Id. ("Unconventional as the arrangement was, it took place in the marketplace for goods and services, not in the investment sphere.").

9. Cf. Robert A. Prentice, Stoneridge, Securities Fraud Litigation, and the Supreme Court, 45 AM. BuS. L.J. 611, 683 (2008) ("The ... holding that collateral parties who knowingly participate in fraudulent schemes are merely 'secondary' parties who cannot be held liable is utterly inconsistent with every relevant body of fraud law in existence in 1934.").

10. As of March 2, 2009, the Dow Jones Industrial Average had lost fifty-five percent of its highest value of 2007. Neil Irwin, In Free-Fall, Stocks Hit Lowest Mark Since '97, WASH. POST, Mar. 3, 2009, at A1. All current economic indicators are down and all forecasts are for a long recession. Recent legislation for more than a trillion dollars in government stimulus spending to help support the economy is further evidence of unprecedented turmoil. 
ever-shrinking national securities legal protection. ${ }^{11}$ This result will also lead to the undesirable situation of more uneven treatment of securities in the national market based on state of incorporation with major variations in the outcomes resulting from variations in the laws, the benches, and the workloads of fifty-one different jurisdictions. ${ }^{12}$ Finally, I further use economic theory to argue that the time is ripe for legislative action with executive leadership to impose civil liability in private actions for aiding and abetting violations of $\S 10(\mathrm{~b})$ of the 1934 Act. Quick action is especially justified in the multiple wakes of the weak economy, crises in the financial sector, loss of confidence in U.S. markets, and the possible elimination of Sarbanes-Oxley. ${ }^{13}$ These forces are merging together into

11. See Mark Klock, Lighthouse or Hidden Reef? Navigating the Fiduciary Duty of Delaware Corporations' Directors in the Wake of Malone, 6 STAN. J.L. BuS. \& FIN. 1, 45 (2001) [hereinafter Klock, Fiduciary Duty] ("Given the procedural restrictions Congress has erected for private actions under the federal securities laws, and given the barriers the federal courts have erected in obtaining judgments against aiders and abettors, the interaction between federal securities laws and state laws pertaining to corporate governance has taken on increased importance. In creating the Delaware carve-out provisions of the Uniform Standards Act, Congress explicitly provided plaintiffs with an alternative forum with different procedural and substantive law to litigate federal securities violations when those violations also constitute a breach of fiduciary duty. The corporate law of Delaware, now more than anytime in the previous sixty-five years, will have a prominent role in protecting the integrity of the marketplace.").

12. See Roberta S. Karmel, Reconciling Federal and State Interests in Securities Regulation in the United States and Europe, 28 BROOK. J. INT'L L. 495 (2003). Professor Karmel writes:

[M] uch state securities regulation over the years has been duplicative, unnecessarily burdensome, and expensive for the securities industry, without adding sufficient value in terms of investor protection. Also, state securities regulation is uneven from state to state and even from administration to administration within a particular state. Further, regulatory competition between national regulators frequently is an unseemly jurisdictional battle fueled by politics. Moreover, such competition can lead to disrespect for the law, as one regulator undermines the laws and regulations of another regulator.

... The reason securities regulation became a matter of federal concern is that there was a need to increase investor confidence in order to generate capital formation in the 1930s. There was also a need to assure against systemic collapses caused by excessive stock market speculation leading to the bursting of the stock market bubble in 1929 and the bankruptcy of numerous financial institutions. State securities regulation and SRO regulation had proved inadequate in performing this task, which was national in scope.

Id. at 544-45 (footnotes omitted).

13. See Jane Bryant Quinn, Lawsuit Threatens Sarbanes-Oxley Act, WASH. Post, July 20, 2008, at F1 ("Just when you thought that the drive toward better financial accounting couldn't be stopped, a stick may be shoved into the spokes. A decision expected soon from a federal court might throw the Sarbanes-Oxley Act into limbo ... because the law lacks a 'severability' clause. If one of its provisions is found to be unconstitutional, the whole law goes down. . . [I]f the court does strike down [Sarbanes-Oxley], it couldn't come at a worse time for investors. The financial crisis linked to subprime loans left the valuation of trillions of dollars of securities in doubt. Nothing is more important to the functioning of markets than pulling reliable numbers out of this morass."). The case referred to later ruled Sarbanes-Oxley to be constitutional, but in a split decision. Free Enter. Fund v. Pub. Co. Accounting Oversight Bd., 537 F.3d 667, 685 (D.C. Cir. 2008). Not surprisingly, the case has been appealed and could be overturned. The Supreme Court agreed to hear the case during the upcoming term. Free Enter. Fund v. Pub. Co. Accounting Oversight Bd., 129 S. Ct. 2378, 2378 
a powerful storm surge overwhelming our formerly deep and liquid securities markets that developed over several decades of nurturing.

\section{BACKGROUND: THE SECURITIES REGULATION LAW ENVIRONMENT}

\section{A. The Outrageous Deception in Stoneridge}

The facts of Stoneridge involve egregious participation in a fraudulent scheme by three corporations: Charter Communications, Scientific-Atlanta, and Motorola. ${ }^{14}$ Stoneridge Investment Partners purchased stock of Charter Communications, a cable company. ${ }^{15}$ In order to falsely inflate corporate revenue, Charter entered into sham contracts with Scientific-Atlanta and Motorola that enabled Charter to claim it had met its projected revenue. ${ }^{16}$ In addition to signing the contracts, Scientific-Atlanta and Motorola assisted Charter in fooling its auditor by drafting documents to make the transactions appear unrelated and part of the ordinary course of business, and by backdating some of the contracts to further create the appearance of being unrelated. ${ }^{17}$ The Court explains the details of the specific action engaged in by ScientificAtlanta and Motorola as follows:

Respondents supplied Charter with the digital cable converter (set top) boxes that Charter furnished to its customers. Charter arranged to overpay respondents $\$ 20$ for each set top box it purchased until the end of the year, with the understanding that respondents would return the overpayment by purchasing advertising from Charter. The transactions, it is alleged, had no economic substance; but, because Charter would then record the advertising purchases as revenue and capitalize its purchase of the set top boxes, in violation of generally accepted accounting principles, the transactions would enable Charter to fool its auditor into approving a financial statement showing it met projected revenue and operating cash flow numbers. Respondents agreed to the arrangement.

In other words, the sham transaction would create artificial revenue on the books for the current fiscal year without fully offsetting costs because the accompanying costs (overpayments) would be amortized over several

(2009).

14. Stoneridge Inv. Partners, LLC v. Scientific-Atlanta, Inc., 128 S. Ct. 761, 766 (2008).

15. Id.

16. Id. at $766-67$.

17. Id. at 767 .

18. Id. at 766 (emphasis added). 
years. ${ }^{19}$ The sham transactions created phony revenue of $\$ 17$ million for the year. $^{20}$ As markets capitalize these revenues, this would be equivalent to creating more than $\$ 200$ million in equity value by fraud. ${ }^{21}$

As Professor Robert Prentice describes these facts, Stoneridge is a simple case of $A$ participating in a scheme to aid $B$ in defrauding $C{ }^{22}$ In this case, $B$ - Charter-ultimately failed and the defrauded investor sought to recover from the $A \mathrm{~s}$-Scientific-Atlanta and Motorola. The transaction is not materially different from a situation in which a coconspirator helps to deceive a home appraiser and assists a "buyer" in obtaining funds fraudulently by appraising a worthless outhouse as a $\$ 400,000$ home for which a lender loans $\$ 380,000$ that the "buyer" transfers to a close relative who is selling the property. ${ }^{23}$ The "buyer" then defaults and vanishes (as does the seller) and the lender's only asset is the remaining worthless collateral. ${ }^{24}$

Such an analogy shows the deceptive nature of the conduct at issue. Yet, to summarize the opinion, which will be analyzed in more detail infra, the Court found that the facts showed the respondents at most aided and abetted a violation of $\S 10(\mathrm{~b}){ }^{25}$ This holding then opened the door for an eager Court to make the ruling it strongly desired- that there continues to be no private cause of action for aiding and abetting even though Congress expressly brought back aiding and abetting liability in Securities and Exchange Commission (SEC) enforcement actions in the

19. See generally Shyam Sunder, Theory of Accounting AND CONTROL 65-79 (1997) (discussing problems and conflicts underlying the measurement of income); Mark Klock, Two Possible Answers to the Enron Experience: Will It Be Regulation of Fortune Tellers or Rebirth of Secondary Liability?, 28 J. CORP. L. 69, 94-100 (2003) [hereinafter Klock, Fortune Tellers] (explaining the difficulty of estimating earnings and income when costs must be allocated over different time periods).

20. Stoneridge, $128 \mathrm{~S}$. Ct. at 767.

21. Annual earnings of $\$ 17$ million with no future growth capitalized at 8.5 percent would be valued at $\$ 200$ million in the financial market. This rate was a reasonable capitalization rate in 2000 when the fraud occurred. Market expectations for growth in earnings would add substantially to this valuation. See generally LaWrence E. Mitchell et AL., CorPorate FinanCE AND GovernanCe 138-39 (3d ed. 2006) (explaining the valuation of corporate earnings using a capitalization rate methodology).

22. Prentice, supra note 9 , at 613.

23. $C f$. id. (describing hypothetical where Sam misrepresents Joe's assets and credit worthiness to Mary to enable Joe to purchase stock on credit from Mary).

24. $C f$. Financial Crimes Enforcement Network Regulatory Policy and Programs Division, MORTAGage LOAN FraUd: AN INDUSTRY ASSESSMENT BASED UPON SUSPICIOUS ACTIVITY REPORT ANALYSIS 14-15 (2006), http://www.fincen.gov/news_room/rp/reports /pdf/MortgageLoanFraud112006.pdf (reporting more than 2.5 percent of mortgage fraud involving the use of straw buyers).

25. Stoneridge, $128 \mathrm{~S}$. Ct. at 771. 
wake of outrage over the Court's initial blanket elimination of the wellestablished doctrine of aiding and abetting liability in Central Bank. ${ }^{26}$

I, like many other securities law commentators and at least three Supreme Court Justices, ${ }^{27}$ believe that the Court construed the law too narrowly and that the defendants should have been liable as either primary participants in a scheme to defraud buyers of securities or through a theory of secondary liability. I also believe that the law must incorporate secondary liability in private actions before confidence in the market can be fully restored to the high levels that brought economic prosperity in the past. ${ }^{28}$ Senator Carl Levin recently stated:

In Stoneridge, the Supreme Court determined that shareholders are barred by federal law from suing third parties that help public companies commit fraud, and must instead rely on federal regulators to punish wrongdoing and recover funds. Given limited federal resources, however, that ruling means, in too many cases, banks, accounting firms, lawyers and others will be able to aid and abet corporate fraud, and shareholders will have no legal recourse. That isn't fair, and it undermines investor confidence in U.S. markets. ${ }^{29}$

But to fully understand the impact of the Stoneridge decision, it is helpful to examine the rise and fall of the doctrine of secondary liability within the federal securities laws.

\section{B. Pre-Stoneridge Securities Laws: A Brief History}

Secondary liability in the context of the federal securities laws arises in conjunction with a primary violation when an additional party which is not primarily liable (perhaps because that party did not sell securities) renders assistance to the primary violator. ${ }^{30}$ "Secondary liability is an issue normally present whenever there is a violation of the federal

26. See id. at 777-78 (Stevens, J., dissenting).

27. See id. at 781-82.

28. See Klock, Fortune Tellers, supra note 19, at 109 ("The vehicle for attaining full and fair disclosure is attachment of civil liability for anything less, and given the vital role ... in protecting the integrity of the market, statutes should be amended to expressly provide for aiding and abetting liability in circumstances in which case law has denied it.").

29. Where Were The Watchdogs? Financial Crisis and the Breakdown of Financial Governance: Hearing Before the S. Comm. on Homeland Sec. \& Gov. Affairs, 111th Cong. [hereinafter Levin] (2009) (statement of Sen. Carl Levin, Chairman Perm. Subcomm. on Investigations).

30. See William H. Kuehnle, Secondary Liability Under the Federal Securities Laws-Aiding and Abetting, Conspiracy, Controlling Person, and Agency: Common-Law Principles and The Statutory Scheme, 14 J. CORP. L. 313, 314 (1989). 
securities laws." 31 Before 1994 one could state with accuracy that "[g]eneral standards for several types of secondary liability under the federal securities laws have come to be accepted widely. The commonly recognized forms of secondary liability are aiding and abetting, conspiracy, controlling person liability, and agency liability ....,32

Prior to the Supreme Court's 1994 ruling in Central Bank, the imposition of secondary liability for violations of $\S 10(\mathrm{~b})$ was established case law in every circuit. ${ }^{33}$ There were two accepted doctrines for imposing liability on secondary participants that would be applicable to Scientific-Atlanta and Motorola under the Stoneridge facts. One is the foreseeable reliance doctrine, which holds the secondary actor liable if the actor knows a wrong is being committed and provides assistance to the violator on which the victim would foreseeably rely. ${ }^{34}$ This clearly would apply under the facts assumed in the Stoneridge decision because the backdating of the documents to mislead the auditors about the lack of a connection between the higher selling price and increased advertising sales implies that the secondary defendants did foresee that the victims would rely on their actions. The second previously applicable doctrine held the aider liable when the aider knows about the wrongdoing and receives a benefit from his assistance. ${ }^{35}$ In this case, Motorola and Scientific-Atlanta benefited from continued revenue that they obtained from Charter by keeping Charter out of bankruptcy for an extended period of time.

It is also important to note that under the historical doctrines, liability could be imposed by finding the defendant had constructive knowledge, acted recklessly, or even assisted by inaction rather than action, although a high standard of intent would be required in such inaction cases. ${ }^{36}$

\footnotetext{
31. Id.

32. Id. at $314-15$.

33. Cent. Bank of Denver, N.A. v. First Interstate Bank of Denver, N.A., 511 U.S. 164, 192 (1994) (Stevens, J., dissenting). See also James D. Cox, Just Deserts for Accountants and Attorneys After Bank of Denver, 38 ARIZ. L. REV. 519, 545 (1996) (aiding and abetting liability for implied private actions under the securities laws "had not only been accepted by all the circuits but had matured and become predictable, and there was no evidence the doctrine had created mischief in its wake").

34. Woods v. Barnett Bank of Fort Lauderdale, 765 F.2d 1004, 1011 (11th Cir. 1985) ("Several courts have applied a recklessness standard to alleged aiders and abettors who have issued statements or certifications foreseeably relied upon by investors, reasoning that a duty to disclose arises under such circumstances.").

35. Walck v. Am. Stock Exch., Inc., 687 F.2d 778, 791 n.18 (3d Cir. 1982).

36. See, e.g., Rolf v. Blyth, Eastman Dillon \& Co., 570 F.2d 38, 44 (2d Cir. 1978) (concluding that a failure to act in the presence of a duty satisfies the scienter requirement of aiding and abetting liability under Section 10(b))
} 
Prior to the Court's ruling in Central Bank, the most comprehensive discussion supporting aiding and abetting liability was compiled by William Kuehnle. At that time Kuehnle asserted:

Although secondary liability is not expressly provided for in the federal securities statutes, except for the "controlling person" provisions and certain limited references to other forms of secondary liability, it has become so well established in the securities law that courts rarely question its basis....

Secondary liability, including liability for commercial fraud, long had been a recognized feature of civil common law at the time of the enactment of the federal securities laws. Congress undoubtedly was aware of this when it enacted the laws. There is also no doubt that Congress intended the securities laws to provide protections that were at least as good as those which existed at common law. If long established concepts of common-law secondary liability were to be excluded from the federal securities laws, the protections provided to investors would be less in many cases than those that existed at common law. Such a result seems incompatible with the intended purposes of the federal securities laws. ${ }^{37}$

Of course, there were some who argued that aiding and abetting liability was inconsistent with the statutory scheme. ${ }^{38}$ Noteworthy among these commentators was Professor Daniel Fischel. ${ }^{39}$ However, all circuits recognized the doctrine. ${ }^{40}$ Even Judge Easterbrook, who was hostile to the doctrine, accepted it as established law. ${ }^{41}$ A few commentators argued that the provisions of the federal securities laws were exclusive and pre-empted common law doctrines of fraud. ${ }^{42}$

37. Kuehnle, supra note 30, at 315-16 (footnotes omitted).

38. See, e.g., Larry D. Soderquist, Securities Regulation: A Problem Approach 39596 (1982); Douglas E. Abrams, The Scope of Liability Under Section 12 of the Securities Act of 1933: "Participation" and the Pertinent Legislative Materials, 15 FordHAM URB. L.J. 877, 924 (1987); Patricia A. O'Hara, Erosion of the Privity Requirement in Section 12(2) of the Securities Act of 1933: The Expanded Meaning of Seller, 31 UCLA L. REV. 921, 1002 (1984).

39. See Daniel R. Fischel, Secondary Liability Under Section 10(b) of the Securities Act of 1934, 69 CAL. L. REV. 80, 98 (1981) (citing Santa Fe Indus. v. Green, 430 U.S. 462, 477 (1977); Ernst \& Ernst v. Hochfelder, 425 U.S. 185, 201 (1976)) ("Where the language of a statute is sufficiently clear - and the failure of Congress expressly to prohibit aiding and abetting, conspiring with, or employing a primary violator when contrasted with the controlling person restrictions could not be clearer-such language is dispositive without resort to legislative history.").

40. Cent. Bank of Denver, N.A. v. First Interstate Bank of Denver, N.A., 511 U.S. 164, 192 (1994) (Stevens, J., dissenting).

41. DiLeo v. Ernst \& Young, 901 F.2d 624, 628 (7th Cir. 1990) ("Our court is the home of the leading case supporting liability for aiders and abettors ... and we stand by this conclusion until a higher court, not bound by our $20+$ years' precedent, resolves it.").

42. See, e.g., Fischel, supra note 39, at 97 (arguing that the express means of imposing 
However, these views were heavily discounted. ${ }^{43}$ While it is true that Congress did not put in a clause expressly providing for secondary liability in the context of violations of $\S 10(\mathrm{~b})$, the argument cuts both ways: "Congress could have made, but did not make, any express statement in the controlling person provisions that those provisions are the exclusive basis for secondary liability. Proponents of exclusivity have a heavy burden to establish that Congress meant something that it easily could have said, but failed to say." 44

Indeed, Congress clearly stated, and the Court had earlier read, that the remedies under the federal securities laws are cumulative and in addition to remedies existing at common law. As the Court wrote in 1983:

In saving clauses included in the 1933 and 1934 Acts, Congress rejected the notion that the express remedies of the securities laws would pre-empt all other rights of action. Section 16 of the 1933 Act states unequivocally that " $[\mathrm{t}] \mathrm{he}$ rights and remedies provided by this title shall be in addition to any and all other rights and remedies that may exist at law or in equity." Section 28(a) of the 1934 Act contains a parallel provision. These provisions confirm that the remedies in each Act were to be supplemented by "any and all" additional remedies. ${ }^{45}$

The Court further observed that "a cumulative construction of the securities laws also furthers their broad remedial purpose" ${ }^{\text {"46 }}$ and embraced the theory that Congress ratified judicial interpretations providing broad implied remedies to securities fraud. ${ }^{47}$ This language

secondary liability are the exclusive means).

43. See, e.g., Marc I. Steinberg, The Ramifications of Recent U.S. Supreme Court Decisions on Federal and State Securities Regulation, 70 Notre DAME L. ReV. 489, 498 (1995) ("Prior to Central Bank of Denver, the lower federal courts overwhelmingly held that aiding and abetting liability was appropriate under section 10(b) of the Exchange Act.").

44. Kuehnle, supra note 30 , at 316 (footnote omitted).

45. Herman \& MacLean v. Huddleston, 459 U.S. 375, 383 (1983) (citing 15 U.S.C. §§ 77p, $78 \mathrm{bb}(\mathrm{a}))$.

46. Id. at 386

47. Id. at 384-86 ("This cumulative construction of the remedies under the 1933 and 1934 Acts is also supported by the fact that, when Congress comprehensively revised the securities laws in 1975 , a consistent line of judicial decisions had permitted plaintiffs to sue under $\S 10$ (b) regardless of the availability of express remedies. In 1975 Congress enacted the 'most substantial and significant revision of this country's Federal securities laws since the passage of the Securities Exchange Act in 1934.' When Congress acted, federal courts had consistently and routinely permitted a plaintiff to proceed under $\S 10(\mathrm{~b})$ even where express remedies under $\S 11$ or other provisions were available. In light of this well-established judicial interpretation, Congress' decision to leave $\S 10(\mathrm{~b})$ intact suggests that Congress ratified the cumulative nature of the $\S 10(\mathrm{~b})$ action." (citation and footnotes omitted)). 
renders a narrow construction of remedies suspect. ${ }^{48}$ Considering the historical context of the 1934 Exchange Act, it is not credible to suggest that Congress intended to reduce remedies. ${ }^{49}$ As I wrote in 1990:

Arguments against applying aiding and abetting to federal securities laws are refuted by the statutory language, legislative history, and recent Supreme Court decisions. The Securities Act and Exchange Act each contain savings clauses that state: "The rights and remedies provided by this title shall be in addition to any and all other rights and remedies that may exist at law or in equity."

These twenty-year-old pre-Central Bank arguments are still being used today in connection with Stoneridge. ${ }^{51}$

Professor Prentice fairly characterizes Stoneridge as a classic " $A$ helps $B$ fool $C$ " case which previously always had resulted in punishment for $A$ until the Stoneridge Court labeled the scenario a standard business practice. $^{52}$ The arguments for secondary liability are still persuasive, but thus far the Court has not responded favorably and new arguments are needed to induce Congress and the President to act in the wake of our economic and financial crises. ${ }^{53}$ The need for secondary liability is not solely to provide remedies for isolated investors defrauded by bankrupt parties with assistance for profit by solvent and culpable secondary actors. Secondary liability is also needed to create incentives for ethical corporate behavior and restore investor confidence in the national market for securities. ${ }^{54}$ The integrity of our entire market is at risk. Capital is being drained and the economy is floundering. The Court's decisions are incentivizing and encouraging further unethical behavior in the markets, and we must put a stop to it before we have many more Enrons and Madoffs.

48. Cf. Prentice, supra note 9, at 612-13 ("[T] he Stoneridge majority opinion . . . represents ... an activist opinion driven primarily by undisguised and quite debatable policy preferences.").

49. Cf. id. at 612 ("[A] majority faction of the Supreme Court ruled... that the Section 10 (b)/Rule 10b-5 cause of action actually provides markedly less protection than investors enjoyed before 1934 rather than more.").

50. Mark S. Klock, Death of a Theory: Pinter v. Dahl and the Scope of Liability Under Section 12(2) of the Securities Act, 17 SEC. REG. L.J. 408, 421 (1990) (citing 15 U.S.C. $\S \S 77$ o, $78 \mathrm{t}$ (1982)).

51. See supra notes 48 and 49 and accompanying text.

52. Prentice, supra note 9 , at 615 .

53. See Levin, supra note 29 ("The current financial crisis has exposed fundamental flaws in U.S. financial regulation and demonstrates why it is an absolute necessity to correct them.").

54. Id. ("Legislation reversing Stoneridge would restore civil liability for aiders and abettors of corporate fraud.”). 


\section{Central Bank and the Erosion of Secondary Liability}

The Supreme Court threw the securities bar for a loop when it announced its decision in Central Bank of Denver v. First Interstate Bank of Denver, provoking much sharp commentary. ${ }^{55}$ One commentator characterized it this way:

In a decision that delighted "deep pockets," shocked the plaintiffs' bar, and befuddled neutral observers, the Supreme Court ... held that aiding and abetting liability in private actions may not be imposed under section 10(b) of the Securities Exchange Act of $1934 \ldots$ or under rule 10b-5. The Court's decision swept away decades of lower court precedent that nearly universally recognized the propriety of such secondary liability under the statute and rule. ${ }^{56}$

Central Bank was responsible for delaying an independent review of an out of date appraisal on real estate used as collateral in a large bond issue. ${ }^{57}$ When the borrowers defaulted soon after the issue, litigation was brought against Central Bank. ${ }^{58}$ Although Central Bank did not actively participate in the fraud, its conduct could be found to be reckless and the Tenth Circuit Court of Appeals held that Central Bank could be liable for aiding and abetting violations of $\S 10(\mathrm{~b}) .^{59}$

The Supreme Court reversed. ${ }^{60}$ The five-to-four majority ruled that the existing private right of action under $\S 10(\mathrm{~b})$ and Rule 10b-5affirmed in Blue Chip Stamps v. Manor Drug Stores ${ }^{61}$ and its progenydid not cover aiding and abetting violations because aiding and abetting lacks "connection with the purchase or sale." 62 The determination of who is a seller under $\S 12$ previously had been construed narrowly by the Court in Pinter v. Dahl, ${ }^{63}$ and the Court chose to continue the narrow construction of who is a seller and apply it to the "connection with the purchase or sale" language under $\S 10(\mathrm{~b}) .{ }^{64}$ "The Supreme Court

\footnotetext{
55. See, e.g., Steinberg, supra note 43, at 490 (calling the Court's disregard for investor protection from fraud "callous").

56. Id. at 489 (citations omitted).

57. Cent. Bank of Denver, N.A. v. First Interstate Bank of Denver, N.A., 511 U.S. 164, 167-68 (1994).

58. Id. at 168

59. Id. at $168-69$.

60. Id. at 192 .

61. 421 U.S. $723,732-49$ (1975) (considering the limitations on the class of plaintiffs that can maintain a private cause of action under Section 10(b)).

62. Central Bank, 511 U.S. at 173, 175-77.

63. 486 U.S. 622, 653-55 (1988).

64. Central Bank, 511 U.S. at 173.
} 
discarded a doctrine that had not only been accepted by all the circuits but had matured and become predictable, and there was no evidence the doctrine had created mischief in its wake." ${ }^{~} 5$ In a sharply worded dissent, Justice Stevens wrote:

In hundreds of judicial and administrative proceedings in every Circuit in the federal system, the courts and the SEC have concluded that aiders and abettors are subject to liability under $\S 10(\mathrm{~b})$ and Rule 10b-5. While we have reserved decision on the legitimacy of the theory in two cases that did not present it, all 11 Courts of Appeals to have considered the question have recognized a private cause of action against aiders and abettors under $\S 10$ (b) and Rule 10b-5. The early aiding and abetting decisions relied upon principles borrowed from tort law; in those cases, judges closer to the times and climate of the $73 \mathrm{~d}$ Congress than we concluded that holding aiders and abettors liable was consonant with the Exchange Act's purpose to strengthen the antifraud remedies of the common law. One described the aiding and abetting theory, grounded in "general principles of tort law," as a "logical and natural complement" to the private $\S 10$ (b) action that furthered the Exchange Act's purpose of "creation and maintenance of a postissuance securities market that is free from fraudulent practices."

The Supreme Court's hostility toward private actions became even more transparent after its decision in Gustafson v. Alloyed Co. ${ }^{67}$ The five-to-four Gustafson majority declared that the private right of rescission under $\S 12(2)$ of the Securities Act of 1933 ("1933 Act") for material misrepresentations in a prospectus did not apply to private sales in a secondary distribution by a controlling shareholder. ${ }^{68}$ This novel rule was fabricated without foundations. ${ }^{69}$ As I have previously stated,

65. Cox, supra note 33 , at 545 .

66. Central Bank, 511 U.S. at 192-93 (Stevens, J., dissenting) (quoting Brennan v. Midwestern United Life Ins. Co., 259 F. Supp. 673, 680 (N.D. Ind. 1966)) (citations and footnotes omitted).

67. 513 U.S. 561 (1995).

68. Id. at 584 .

69. See id. at 584-88 (Thomas, J., dissenting). Justice Thomas concludes:

The majority's analysis of $\S 12(2)$ is motivated by its policy preferences. Underlying its reasoning is the assumption that Congress could never have intended to impose liability on sellers engaged in secondary transactions. Adopting a chiding tone, the majority states that "[w]e are reluctant to conclude that $\$ 12(2)$ creates vast additional liabilities that are quite independent of the new substantive obligations that the Act imposes." Yet, this is exactly what Congress did in § 17(a) of the 1933 Act as well as in $\S 10$ (b) of the 1934 Act. Later, the majority says: "It is not plausible to infer that Congress created this extensive liability for every casual communication between buyer and seller in the secondary market." It is not the usual practice of this Court to require Congress to explain why it has chosen to pursue a certain policy. Our job simply is to apply the policy, not to question it. 
"[t]he decision [in Gustafson] is so poorly reasoned and so contrary to the sixty years of thinking and practicing under the Securities Act that bias flashes on every page. Gustafson has been described as 'the most poorly-reasoned, blatantly results-driven securities opinion in recent memory." "70

\section{The Private Securities Litigation Reform Act}

Another complication in the rise and fall of secondary liability prior to Stoneridge is Congress's 1995 legislation titled the Private Securities Litigation Reform Act (PSLRA). ${ }^{71}$ The major thrust of the Act was to erect procedural barriers in securities class actions in order to reduce perceived abuses in non-meritorious strike suits. ${ }^{72}$ Much commentary and debate surrounded both the empirical basis for the Act as well as its likely effects. ${ }^{73}$ However, one important provision was included in the Act in reaction to Central Bank. ${ }^{74}$ That provision expressly authorized

Unfortunately, the majority's decision to pursue its policy preferences comes at the price of disrupting the process of statutory interpretation. The majority's method turns on its head the commonsense approach to interpreting legal documents. ...

The majority's methodology also has the effect of frustrating Congress' will.... The majority does not permit Congress to implement its intent unless it does so exactly as the Court wants it to.

Id. at 594-96 (internal citations omitted).

70. Stephen M. Bainbridge, Securities Act Section 12(2) After the Gustafson Debacle, 50 Bus. LAW. 1231, 1231-32 (1995); Klock, Fiduciary Duty, supra note 11, at 43.

71. Pub. L. No. 104-67, 109 Stat. 737 (codified at 15 U.S.C. $\S \S 77 z-1,77-2,78 j-1,78 u-4,78 u-$ $5(2006))$.

72. See, e.g., Elliot J. Weiss, The Lead Plaintiff Provisions of the PSLRA After a Decade, or "Look What's Happened to My Baby", 61 VAND. L. REV. 543, 547 (2008) ("These data led us to conclude that if class action procedures could be reformed [it would] ... reduce substantially the agency costs associated with securities class action litigation.").

73. Compare Willard T. Carleton et al., Securities Class Action Lawsuits: A Descriptive Study, 38 ARIZ. L. REV. 491, 492 (1996) (finding evidence of nuisance suits) with Edward Labaton, A View From the Trenches, 38 ARIZ. L. REV. 513, 513-14 (1996) (criticizing studies for defining settlements under \$2 million as "nuisance" suits when cases are often settled for under \$2 million due to insurance limits, insolvency, and other reasons and further stating that frivolous suits in the class action area are small because attorneys do not take cases which will not earn them a living). For further criticism of the Act's empirical basis, see Janet Cooper Alexander, Do the Merits Matter? A Study of Settlements in Securities Class Actions, 43 STAN. L. REV. 497, 597 (1991) (suggesting that securities class action settlements do not reflect the merits and that shareholder derivative suits suffer from the same criticism). But note that Professor Alexander's conclusions are based on a sample of only nine companies. Id. at $517 \mathrm{tbl}$. 4. And they involve only initial public offerings of computer and computer related companies during six months of 1983. Id. at 507. The empirical facts continue to be debated more than a decade later. See generally, James D. Cox et al., There Are Plaintiffs and... There Are Plaintiffs: An Empirical Analysis of Securities Class Action Settlements, 61 VAND. L. REV. 355, 355-86 (2008).

74. See Stoneridge Inv. Partners, LLC v. Scientific-Atlanta, Inc., 128 S. Ct. 761, 768 (2008) ("The decision in Central Bank led to calls for Congress to create an express cause of action for 
the SEC to bring enforcement actions for aiding and abetting violations of federal securities laws. ${ }^{75}$

Unfortunately, the Act was silent as to whether private actions for damages could pursue aiders and abettors. ${ }^{76}$ Thus, the Act provided some arguments on both sides. ${ }^{77}$ By expressly authorizing the SEC to pursue aiding and abetting violations it is at least arguable that Congress legislatively overturned the Central Bank decision by expressly making aiding and abetting violations of $\S 10(\mathrm{~b})$ and Rule $10 \mathrm{~b}-5$ illegal. ${ }^{78}$ On the other hand, by expressly providing for secondary liability in SEC enforcement actions and considering, but not doing so for private enforcement actions, Congress arguably affirmed Central Bank with respect to private enforcement. ${ }^{79}$

Nevertheless, even if Congress did not wish for private victims of $\S$ 10 (b) violations to have a cause of action against aiders and abettors, that does not imply that Congress intended to exempt from liability those secondary actors who participated at a higher level than mere aiding and abetting. ${ }^{80}$ In particular, the Ninth Circuit approved of the theory of scheme liability. ${ }^{81}$ Under this theory, tortfeasors that did not actually purchase or sell a security could be liable if they participated with the seller in a scheme to defraud investors. ${ }^{82}$ This provides the setting for Stoneridge, which gave the Court an opportunity to decide the argument.

\section{The Stoneridge Decision and Analysis}

\section{The Majority Opinion}

The holding of Stoneridge is hard to fathom. The Court began its opinion with a short and sweet summary of its conclusion in the first paragraph:

\footnotetext{
aiding and abetting within the Securities Exchange Act.”).

75. Private Securities Litigation Reform Act of $1995 \S 104,15$ U.S.C. 78t(e) (2006).

76. Stoneridge, $128 \mathrm{~S}$. Ct. at $768-69$.

77. See generally Prentice, supra note 9, at 648-51 (discussing arguments on both sides relating to the legislative intent underlying legislation expressly providing for SEC prosecution for aiding and abetting violations of $\S 10$ (b) while keeping silent on private rights of action).

78. See id. at 650-51 (arguing that Congress granted the SEC power to use those convicted of aiding and abetting under $\S 10$ (b) because the Central Bank decision did not address this possibility).

79. Stoneridge, $128 \mathrm{~S}$. Ct. at $768-69$.

80. Id. at 778-79 (Stevens, J., dissenting).

81. Simpson v. AOL Time Warner Inc., 452 F.3d 1040, 1049 (9th Cir. 2006), judgment vacated, Avis Budget Group, Inc. v. Cal. State Teachers' Ret. Sys., 128 S. Ct. 1119 (2008), opinion vacated, Simpson v. Homestore, 519 F. 3d 101 (9th Cir. 2008).

82. Simpson, 452 F.3d at 1049-50.
} 
In this suit investors alleged losses after purchasing common stock. They sought to impose liability on entities who, acting both as customers and suppliers, agreed to arrangements that allowed the investors' company to mislead its auditor and issue a misleading financial statement affecting the stock price. We conclude the implied right of action does not reach the customer/supplier companies because the investors did not rely upon their statements or representations.

In other words, the Court concluded that because the defendant customers and suppliers only participated in the sham transactions but did not create the financial reports that relied on the sham transactions, they are not liable to the victims of the fraud. ${ }^{84}$ I cannot recall a Supreme Court opinion with a more callous analysis of causation.

The Court's decision that the fraud committed by the aiders and abettors was too remote to be "connected" with the purchase or sale of the securities ${ }^{85}$ at issue was a key error. ${ }^{86}$ Notwithstanding the majority's assertion to the contrary, a moment of reflection about the possible motivation for falsely amortizing current expenses and booking nonexistent revenue in public filings with the SEC necessarily leads one to conclude that the primary intent was to promote the sale of securities at an inflated price. ${ }^{87}$ There is no alternative economic incentive to engage in such conduct. Indeed, this analysis of intent is a textbook illustration of the principle of res ipsa loquitur. ${ }^{88}$

To begin, note that the reason corporate officers are tempted to overstate earnings is to inflate stock prices. A discussion of this temptation can be found in the ethics chapter of an introductory finance textbook. ${ }^{89}$ Common sense tells that the purpose of requiring publicly filed financials to be signed off by a certifying accountant is to make it difficult for corporate officers to overstate earnings and to provide investors with a minimal degree of confidence that the earnings estimates are fairly reported. ${ }^{90}$ Finally, it is also obvious that the reason that other

83. Stoneridge, $128 \mathrm{~S}$. Ct. at 766.

84. Id. at 774 .

85. Id. at $770-71$.

86. Id. at 774-75 (Stevens, J., dissenting).

87. $C f$. Ivo Welch, Corporate Finance: An InTroduction 906 (2009) ("Usually, fraud involves manipulation of financials.").

88. See Donald C. Langevoort, Organized Illusions: A Behavioral Theory of Why Corporations Mislead Stock Market Investors (and Cause Other Social Harms), 146 U. PA. L. REV. 101, 110-14 (1998) (discussing why managers introduce misleading information into the stock market).

89. See generally WELCH, supra note 87 , at 896-943 (chapter on corporate governance covering managerial conflicts of interests and an extensive menu of tactics used by managers to enrich themselves).

90. See SUNDER, supra note 19, at 124 ("The public believes that auditors are responsible for 
corporations would engage in sham transactions and draft documents to disguise the related transactions as unrelated is to deceive the auditors and perpetrate a fraud in the public market for stock. ${ }^{91}$

Two legal points are worth observing here. First, these res ipsa loquitur factual conclusions appear on their face to satisfy the plain language of the 1934 Act, which prohibits, directly or indirectly, the employment of a device or scheme to defraud any person "in connection with the purchase or sale of any security." leaps that have been used by some Justices and lower court judges to constrain the meaning of "device" and "connection with" are truly amazing. ${ }^{93}$ Second, the remedies provided by the 1934 Act are cumulative and do not limit investor rights that existed under common law. ${ }^{94}$ Thus, the Stoneridge decision would be amazing were it not for the fact that the securities bar knew in advance of the Court's hostility towards investor class actions against corporations. ${ }^{95}$

Even without reliance on a theory of scheme liability or aiding and abetting liability, Motorola and Scientific-Atlanta were liable as primary participants under the plain language of the statute. ${ }^{96}$ Section $10(\mathrm{~b})$ makes it illegal "to use or employ, in connection with the purchase or sale of any security registered on a national securities exchange ... any manipulative or deceptive device or contrivance in contravention of such

the detection of fraud. Indeed, they see it as the reason why they are willing to pay for the audit.").

91. Indeed, the Stoneridge majority opinion observed this obvious point:

So that Arthur Andersen would not discover the link between Charter's increased payments for the boxes and the advertising purchases, the companies drafted documents to make it appear the transactions were unrelated and conducted in the ordinary course of business....

... The backdating was important to convey the impression that the negotiations were unconnected, a point Arthur Andersen considered necessary for separate treatment of the transactions.

Stoneridge, 128 S. Ct. at 767.

92. Securities Exchange Act of 1934 § 10(b), 15 U.S.C. § 78j (2006).

93. Describing the Stoneridge majority's argument, Professor Prentice wrote:

The Stoneridge majority noted that the language of Section 10(b) requires that to be actionable a fraud must be "in connection with" a purchase or sale. The Court then declined to examine the in-connection-with requirement. One must suspect that the fact the in-connection-with requirement was obviously met in this case has something to do with that decision.

Prentice, supra note 9, at 658 (citations omitted).

94. 15 U.S.C. $\S 78 \mathrm{bb}$ ("[T] $]$ he rights and remedies provided by this chapter shall be in addition to any and all other rights and remedies that may exist at law or in equity ...."). See also MARC I. SteinBerg, SECuRities Regulation 622-24 (2004) (discussing the legal basis for a cumulative remedies approach).

95. Stoneridge, 128 S. Ct. at 779 (Stevens, J., dissenting) ("A theme that underlies the Court's analysis is its mistaken hostility towards the $\S 10($ b) private cause of action.").

96. Id. at 774 . 
rules and regulations as the Commission may prescribe ...."97 Rule 10b-5, adopted by the SEC under the authority of $\S 10(\mathrm{~b})$, makes it unlawful "to engage in any act, practice, or course of business which operates or would operate as a fraud or deceit upon any person, in connection with the purchase or sale of any security." "98 The majority decision turns on the causal "connection with the purchase or sale of any security." $" 99$

The short answer to the question as to whether the conduct provided the sufficient causal connection is given by Basic Inc. v. Levinson. ${ }^{100}$ In Basic the Court held the reliance requirement could be established by reliance on a price in a public market containing false information. ${ }^{101}$ This is the well known fraud-on-the-market theory. ${ }^{102}$ Basic has never been overruled, and prior to Stoneridge the Court had never held that investors must be aware of the specific conduct. ${ }^{103}$ The Stoneridge majority did not dispute the contention that the victims relied on the market price and would not have bought the stock at that price had the victims known of the fraud. ${ }^{104}$ The Court held instead that the sham transactions were too remote to the purchase. ${ }^{105}$ What the majority failed to consider is that under the statutory scheme investors should be entitled

97. 15 U.S.C. § 78 j.

98. 17 C.F.R. $\S 240.10 b-5(c)(2009)$.

99. See Stoneridge, $128 \mathrm{~S}$. Ct. at 774-75 (Stevens, J., dissenting) (criticizing the majority's view that reliance requires super-causation in the purchase of securities).

100. 485 U.S. 224 (1988).

101. See id. at $241-47$ ("Requiring proof of individualized reliance from each member of the proposed plaintiff class effectively would have prevented respondents from proceeding with a class action, since individual issues then would have overwhelmed the common ones. The District Court found that the presumption of reliance created by the fraud-on-the-market theory provided 'a practical resolution to the problem...."'); see also Bradford Cornell \& James C. Rutten, Market Efficiency, Crashes, and Securities Litigation, 81 Tul. L. REV. 443, $443-44$ (2007) ("In Basic Inc. v. Levinson, the United States Supreme Court made it easier for plaintiffs alleging securities fraud under section 10(b) of the Securities Exchange Act of 1934 and Securities and Exchange Commission (SEC) Rule 10b-5 to prove the essential element of reliance. The Court held that under the so-called fraud-on-the-market theory, a plaintiff who purchased securities on an "open and developed" market can be presumed to have relied on the integrity of the market price and in that way to have relied, indirectly, on allegedly false or misleading public statements of the defendants." (footnotes omitted)).

102. See, e.g., Elizabeth Chamblee Burch, Reassessing Damages in Securities Fraud Class Actions, 66 MD. L. REV. 348, 358-59 (2007) (explaining that the efficient market theory provides the basis for reliance and causation); Frederick C. Dunbar \& Dana Heller, Fraud on the Market Meets Behavioral Finance, 31 DEL. J. CORP. L. 455, 458-59 (2006) (describing the fraud-on-themarket theory); Larry E. Ribstein, Fraud on a Noisy Market, 10 LEWIS \& CLARK L. REV. 137, 13839 (2006) (same).

103. Stoneridge, $128 \mathrm{~S}$. Ct. at 776 (Stevens, J., dissenting).

104. Id. at 770 (majority opinion).

105. Id. at 774 . 
to rely on the veracity of the auditors. ${ }^{106}$ Given that Motorola and Scientific-Atlanta backdated some of their agreements and drafted other documents for the purpose of fooling the auditors into believing that the sale of the set-top boxes and the purchase of the advertising were unrelated, how is it logically possible that their misconduct was not related to a fraud on the market in connection with a purchase of securities? ${ }^{107}$ Engaging in sham transactions supported with false documentation calculated to mislead the auditors that certify the financial reports surely provides a causal connection between the deception and the purchase of the securities. ${ }^{108}$ Even though it is true that Charter could have subsequently stopped the fraud, that does not relieve the joint tortfeasors of liability for their bad acts. ${ }^{109}$

For the Court, the key to the decision was the simple fact that the preparation of the financial statements was not contemporaneous with the creation of the backdated and fraudulent transactions to which Scientific and Motorola were participants. ${ }^{110}$ This simplistic analysis is clearly and concisely stated in the concluding paragraph of the opinion:

Unconventional as the arrangement was, it took place in the marketplace for goods and services, not in the investment sphere. Charter was free to do as it chose in preparing its books, conferring with its auditor, and preparing and then issuing its financial statements. In these circumstances the investors cannot be said to have relied upon any of respondents' deceptive acts in the decision to purchase or sell securities; and as the requisite reliance cannot be shown, respondents have no liability to petitioner under the implied right of action.

This analysis is like asserting that the car engine plays no role in the forward movement of a vehicle because the transmission could be shifted

106. $C f$. EDMund L. Jenkins, FinANCIAL ACCOUNTING StANDARDS BoARd, The FASB's Role IN SERVING THE PUBLIC 5-7 (explaining that in order for capital markets to flourish, investors must be able to rely on summary information provided by accountants and assurances given by auditors), available at http://72.3.243.42/news/fasb_role.pdf (last visited Sept. 14, 2009).

107. See Stoneridge, $128 \mathrm{~S}$. Ct. at 775 (Stevens, J., dissenting) ("The allegations in this case ... plainly describe 'deceptive devices' under any standard reading of the phrase.”).

108. Id. at 776-77.

109. See Sinai, supra note 6, at 183 ("Where it is known by the conspirators that the falsified information is going to be distributed to the public and potential investors, that ought to be the basis for the creation of a 'duty' to that group, a duty not to deceive them; not to defraud them.").

110. Stoneridge, $128 \mathrm{~S}$. Ct. at 769 ("No member of the investing public had knowledge, either actual or presumed, of the respondents' deceptive acts during the relevant times. Petitioner, as a result, cannot show reliance upon any of respondents' actions except in an indirect chain that we find too remote for liability.").

111. Id. at 774 . 
to reverse gear. ${ }^{112}$ Even though we can distinguish components of an automotive power train, that does not imply that the distinct components operate independently in isolation. The parts function in connection together. The same is true of markets. Product markets and financial markets are intertwined, and to assert that a fraud could not have met the reliance requirement in the securities market because the fraud took place in the product market is not logical. ${ }^{113}$ The markets are connected like a hammer's head and handle, and when one part is moved the other part necessarily follows. Transactions in the product market directly affect prices in the securities markets. ${ }^{114}$ This is what the prices, which are subjective valuations about the future, are based on. ${ }^{115}$ Additionally, the reporting and misreporting of those transactions in the product market directly affect prices in the securities markets. ${ }^{116}$ The late Professor James Tobin of Yale University received a Nobel Prize in large part for his work explaining the linkage between the market for physical assets and financial markets. ${ }^{117}$ The Stoneridge majority has created a contrived distinction for the purpose of eliminating liability by the perpetrator of a but-for cause of the securities fraud. ${ }^{118}$ The distinction between preparing the financial statements and providing the sham transactions upon which the financial statements were based is arbitrary and whimsical. ${ }^{119}$

Under such a restrictive interpretation of $\S 10(\mathrm{~b})$, there will be few instances in which assisting in fraudulent product-market transactions to

112. $C f$. Prentice, supra note 9 , at 657 (providing analogous hypothetical in which $C$ gives a bogus promissory note to $B$ for a fee knowing that $B$ intends to use the note to defraud $A$, but under Stoneridge, $C$ 's conduct would be too disconnected to impose liability since $B$ could have stopped the fraud).

113. See Mark Klock, The SEC's New Regulation ATS: Placing the Myth of Market Fragmentation Ahead of Economic Theory and Evidence, 51 FLA. L. REV. 753, 778-79 (1999) (explaining that market integration necessitates that "the information contained in transactions in one market is quickly reflected in the other markets so that all the markets effectively operate as a single market").

114. Mark Klock, Mainstream Economics and the Case for Prohibiting Inside Trading, 10 GA. ST. U. L. REV. 297, 323 (1994) [hereinafter Klock, Mainstream Economics] (explaining that markets cannot operate independently and that what happens in one market impacts the other).

115. See Mitchell ET AL., supra note 21, at 105 ("[F]amiliarity with these valuation matters reveals the ephemeral nature of the concept of value. The apparent numerical precision of the endproduct of valuations masks the significant subjectivity of the conclusion.").

116. See SUNDER, supra note 19, at 102-03 (discussing the effects of accounting reports on stock prices).

117. Klock, Mainstream Economics, supra note 114, at 298.

118. See Stoneridge Inv. Partners, LLC v. Scientific-Atlanta, Inc., 128 S. Ct. 761,776 (2008) (Stevens, J., dissenting) (referring to the wash transactions as a but-for cause).

119. Cf. Klock, Fortune Tellers, supra note 19, at 96 (pointing to the inherently whimsical nature of the assumptions underlying financial statements). 
manipulate information in the public marketplace for securities can be found to form a basis for reliance. The lesson seems to be that if the fraudulent transactions can be classified as involving transactions for goods and services rather than transactions for financial products, private actions under the securities laws will not be available no matter how much harm was wrought on the public securities markets. ${ }^{120}$ In the words of one commentator:

Under Stoneridge, a professional can rest easy so long as the attorney, CPA, and investment banker make no statements to the public. It appears no matter their culpability, they will escape private civil liability under $\S 10(\mathrm{~b})$. As mere "aiders and abettors," Stoneridge excludes them from coverage under $\S 10(\mathrm{~b})$ and the Rule. The lawyer that works, plans and schemes with his client to deceive and defraud the investing public, but who is careful to make no public statements, is free of civil liability under the Eighth Circuit's and Supreme Court's current view as expressed in Stoneridge.

The Court also insincerely characterized the case as one involving lack of a duty of disclosure on the part of the vendors and customers of Charter. ${ }^{122}$ Although these vendors and customers do not have an affirmative duty to disclose facts to Charter's stockholders, that does not imply that they have a license to perpetuate fraud against the stockholders. ${ }^{123}$ A duty is created by their misconduct. ${ }^{124}$ The vendors and customers knowingly participated in sham transactions; it is unconscionable for the Court to turn a blind eye to this. Just because one owes no duty to save a drowning victim absent some special relationship does not mean that one can lure the victim into the drowning pool. ${ }^{125}$ This example is perfectly analogous with Stoneridge and the federal securities laws' requirement of reliance. As Kuehnle wrote two decades ago, "[O]ne who helps prepare false statements can be held liable as a

120. See Sinai, supra note 6, at 187 (stating that the Supreme Court has rewritten federal securities law to make private actions inapplicable "unless the 'act' or 'course of business' committed by a defendant is also accompanied by his direct misstatement to investors or the market").

121. Id.

122. Stoneridge, 128 S. Ct. at 769 ("Respondents had no duty to disclose ....").

123. See generally Klock, Fiduciary Duty, supra note 11, at 18-19 (discussing the basis for the proposition that absence of a duty to disclose does not render one immune from liability for misdisclosure and fraud).

124. Sinai, supra note 6, at $183-84$.

125. See Restatement (SECOND) OF TORTS $§ 314 \mathrm{cmt} . \mathrm{d}$ (1965). 
primary violator even if the person is not present when the statements are transmitted to the victim." 126

An exemplary case relying on this analysis in the context of securities fraud was decided by the Delaware Supreme Court in Malone v. Brincat. $^{127}$ In Malone, the directors of a publicly-traded Delaware corporation filed false financial statements with the SEC. ${ }^{128}$ Rather than pursue a claim under the federal securities laws, the plaintiffs brought a claim in state court for breach of fiduciary duty and included defendants who allegedly aided and abetted the breach. ${ }^{129}$ The lower court dismissed the case with prejudice on the theory that directors have no duty of disclosure to shareholders absent a request for shareholder approval. ${ }^{130}$ The Delaware Supreme Court disagreed and held that directors cannot, directly or indirectly, mislead shareholders via corporate disclosures. ${ }^{131}$ In the words of the court:

Delaware law also protects shareholders who receive false communications from directors even in the absence of a request for shareholder action. When the directors are not seeking shareholder action, but are deliberately misinforming shareholders about the business of the corporation, either directly or by a public statement, there is a violation of fiduciary duty.

The Malone Court also held that the accountants who assisted in the preparation of the false financial statements filed with the SEC could be held liable to the shareholders for aiding and abetting a breach of fiduciary duty. ${ }^{133}$ Delaware is not the only state to recognize aiding and abetting a breach of fiduciary duty to shareholders as a basis for legal liability in a shareholder class action. ${ }^{134}$

The fact pattern in Stoneridge shows that Motorola and ScientificAtlanta aided and abetted Charter's breach of fiduciary duties to its shareholders. Because Charter and Motorola are both Delaware corporations and, given the hostility of the United States Supreme Court

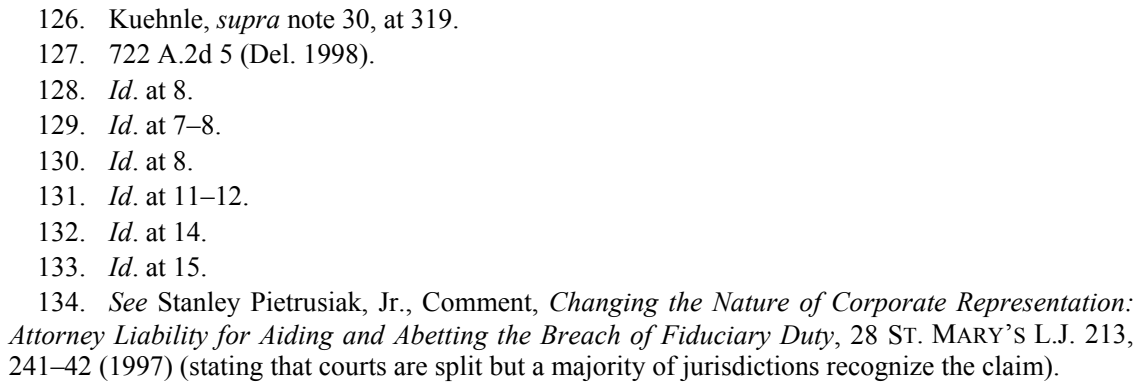


to private actions under the securities laws, one wonders why counsel did not attempt to bring the action in the Delaware state court. The Delaware Supreme Court has further extended Malone's corporate context to apply to the relationship between a broker and a client in O'Malley $v$. Boris. ${ }^{135}$ This finding further highlights the substitution of state corporate law remedies for federal securities law protection under the United States Supreme Court's continued contraction of remedies. ${ }^{136}$ Fragmented state protection in a national market is undesirable and requires congressional action with leadership and support by the new President. ${ }^{137}$

Troubles in the real estate sector lead to troubles in the financial sector, and vice versa. ${ }^{138}$ We cannot protect the integrity of the financial markets if we provide for immunity from civil liability where the fraud is consummated in the product market. ${ }^{139}$ The Stoneridge rule not only permits unethical conduct, it actively encourages unethical conduct with pecuniary rewards. ${ }^{140}$

\section{The Dissenting Opinion}

Justice Stevens, joined by Justices Souter and Ginsburg, harshly criticized the reasoning of the Court and concluded that the alleged conduct of Scientific-Atlanta and Motorola constituted a primary violation of $\S 10(\mathrm{~b}) .^{141}$ The dissent succinctly summarized the case:

Charter Communications, Inc., inflated its revenues by $\$ 17$ million

in order to cover up a $\$ 15$ to $\$ 20$ million expected cash flow shortfall.

It could not have done so absent the knowingly fraudulent actions of

135. 742 A.2d 845, 849-50 (Del. 1999) (drawing an analogy between the broker-client relationship and director-shareholder relationship).

136. See Klock, Fiduciary Duty, supra note 11, at 45 (observing the expanded role of state law in the face of diminishing federal investor protection).

137. See generally Frank B. Cross \& Robert A. Prentice, The Economic Value of Securities Regulation, 28 CARDOZO L. REV. 333, 359-67 (2007) (providing comprehensive theoretical and empirical analysis of the advantages of mandatory federal securities regulation relative to state regulation or privatized regulation or deregulation).

138. See, e.g., Mark J. Roe, Legal Origins, Politics, and Modern Stock Markets, 120 HARV. L. REV. 460, 463-64 (2006) (making the case that strong economic development and strong financial markets are mutually interdependent).

139. See Prentice, supra note 9, at 661-62 (noting that fraud behind the transactions underlying published financial statements deceives the entire market).

140. See Sinai, supra note 6, at 187 (observing that Stoneridge empowers professionals to participate in schemes to deceive and defraud investors as long as they take care to avoid making public statements).

141. Stoneridge Inv. Partners, LLC v. Scientific-Atlanta, Inc., 128 S. Ct. 761, 777 (2008) (Stevens, J., dissenting) ("The Court's view of reliance is unduly stringent and unmoored from authority."). 
Scientific-Atlanta, Inc. and Motorola, Inc. Investors relied on Charter's revenue statements in deciding whether to invest in Charter and in doing so relied on respondents' fraud, which was itself a "deceptive device" prohibited by $\S 10($ b) of the Securities Exchange Act of 1934. This is enough to satisfy the requirements of $\S 10(\mathrm{~b})$ and enough to distinguish this case from Central Bank....

Further explaining the fraudulent acts prohibited by $\S 10(\mathrm{~b})$, the dissent stated that, "[t]he allegations in this case-that respondents produced documents falsely claiming costs had risen and signed contracts they knew to be backdated in order to disguise the connection between the increase in costs and the purchase of advertising - plainly describe 'deceptive devices' under any standard reading of the phrase." "143 This distinguishes Stoneridge from Central Bank because the defendant in Central Bank was not a participant to the fraud. ${ }^{144}$ Central Bank of Denver had only been negligent in delaying an independent real estate appraisal in a declining market before the underlying bond issuance was completed. ${ }^{145}$ That conduct was vastly different from creating sham transactions coupled with false and misleading documentation. ${ }^{146}$

The Court's conclusion that the deceptive acts committed by Scientific-Atlanta and Motorola did not subject them to liability in a private action under $\S 10(\mathrm{~b})$ because the deceptive acts did not directly cause investors harm would be laughable were it not such a serious matter. The Court concluded that the deceptive acts could not possibly have caused the investors' harm essentially because the investors did not know about them. ${ }^{147}$ The elements of $\S 10(\mathrm{~b})$ were satisfied by the allegations that the respondents engaged in a fraud which they knew or should have known would enter the marketplace and the petitioners relied on the market price. The dissenters remarked:

In Basic Inc., [the Court] held that the "fraud-on-the-market" theory provides adequate support for a presumption in private securities actions that shareholders (or former shareholders) in publicly traded companies rely on public material misstatements that affect the price of

142. Id. at 774 (citing 15 U.S.C. $§ 78 \mathrm{j}(\mathrm{b})$ ).

143. Id. at 775 .

144. Id.

145. Central Bank of Denver, N.A. v. First Interstate Bank of Denver, N.A., 511 U.S. 164, $167-$ 68 (1994).

146. Stoneridge, 128 S. Ct. at 775 (Stevens, J., dissenting) ("[T]he facts in Central Bank would mirror those in the case before us today if the bank had knowingly purchased real estate in wash transactions at above-market prices in order to facilitate the appraiser's overvaluation of the security.").

147. Id. at 769 (majority opinion). 
the company's stock. The holding in Basic is surely a sufficient response to the argument that a complaint alleging that deceptive acts which had a material effect on the price of a listed stock should be dismissed because the plaintiffs were not subjectively aware of the deception at the time of the securities' purchase or sale. This Court has not held that investors must be aware of the specific deceptive act which violates $\S 10 \mathrm{~b}$ to demonstrate reliance. ${ }^{14}$

The dissent is buttressed by common law fraud principles. Under common law fraud, the defendants would be liable. ${ }^{149}$ The dissenters observed that although $\S 10$ (b) is not the same as common law fraud, it was intended to be broader "because common-law fraud doctrines might be too restrictive." 150 The dissenters were also critical of the majority for its distinction between the realm of financing and ordinary business transactions:

Because the kind of sham transactions alleged in this complaint are unquestionably isolated departures from the ordinary course of business in the American marketplace, it is hyperbolic for the Court to conclude that petitioner's concept of reliance would authorize actions "against the entire marketplace in which the issuing company operates." 15

Finally, the dissent argues that the majority makes too much out of Congress's omission of aiding and abetting liability with respect to private enforcement. ${ }^{152}$ Even if Congress did not intend to permit private actions for aiding and abetting, it surely did not intend to eliminate private actions against primary participants. ${ }^{153}$

\section{Result-Driven Reasoning?}

The egregious nature of the fraud in Stoneridge seems to be an obvious case for holding the corporations who unethically booked sham transactions to facilitate a profitable relationship liable as primary participants. ${ }^{154}$ This provides credibility for the cynical view that the decision was result-driven. ${ }^{155}$ This view, that the Court was eager to

148. Id. at 776 (Stevens, J., dissenting) (citations omitted).

149. Id. at 777 .

150. Id. (citing Herman \& McLean v. Huddleston, 459 U.S. 375, 388-89 (1983)).

151. Id. at n.4 (quoting majority opinion, 771).

152. Id. at $777-79$.

153. Id. at $778-79$.

154. See id. at 774 ("This [fraudulent action] is enough to satisfy the requirements of $\S$ 10(b) ....").

155. See supra notes 48 and 49 and accompanying text. 
have an opportunity to limit the express cause of action for secondary liability that Congress inserted into the PSLRA, was publicized by early commentators. ${ }^{156}$ In order to have the opportunity to limit the language providing for secondary liability, it was necessary for the Court to reach the conclusion that there was insufficient causal connection between the conduct and the fraud in the financial market. ${ }^{157}$ So the Court ruled that knowingly falsifying dates and documentation on sham transactions to help mislead auditors did not have the requisite causal connection because the sham transactions themselves were not communicated to the investing public. Only the false financial reports that were built on the sham transactions - reports that Scientific-Atlanta and Motorola did not prepare or disseminate - were transmitted to the investing public. ${ }^{158}$ This novel theory used by the majority dichotomizes transactions between the financial markets and the product markets. ${ }^{159}$ Such a dichotomy is a fairytale with no basis in reality. ${ }^{160}$ The markets are so closely connected that they can only be distinguished for pedagogical purposes, not for real-world law making. ${ }^{161}$

The fact that these defendants should have been liable as primary participants under the plain meaning of the statute inevitably leads to the conclusion that the majority wanted to reach a result to unequivocally eliminate liability for "secondary actors" as much as possible in light of Congress's express provision allowing the SEC to bring actions against aiders and abettors effectively making aiding and abetting conduct expressly illegal. Subsequent to Central Bank, the Ninth Circuit embraced the theory of "scheme to defraud liability" for reaching secondary participants in securities fraud in Simpson v. AOL Time Warner. ${ }^{162}$ The theory of scheme liability is that the secondary actors

156. See Prentice, supra note 9, at 668-69 ("Any reading of the Stoneridge opinion clearly indicates that the majority faction was uncommonly determined to read Section 10(b) in an exceedingly stinting fashion.").

157. See id. at 651 (explaining that because the Stoneridge defendants were involved in such blatant fraud, the majority could not merely label them aiders and abettors without first ruling erroneously that the investors did not rely on the defendants' acts).

158. Stoneridge, $128 \mathrm{~S}$. Ct. at 774 (majority opinion).

159. See id. at 770 (effectively asserting that investors in an efficient market are only entitled to rely on the financial statements, not the transactions underlying the financials).

160. See Joseph E. Stiglitz, Principles of Microeconomics (2d ed. 1997). Professor Stiglitz explains that a change in one market will lead to a new equilibrium for the whole economy. "Competitive general equilibrium entails prices, wages, and returns to capital such that all marketsfor goods, labor, capital (and other factors of production)_clear.” Id. at 318.

161. See id. at 226 ("The two markets are linked: the financial investments people make provide firms with the funds they need to undertake real investments.").

162. 452 F.3d 1040, 1049 (9th Cir. 2006), judgment vacated, Avis Budget Group, Inc. v. Cal. State Teachers' Ret. Sys., 128 S. Ct. 1119 (2008), opinion vacated, Simpson v. Homestore, 519 F.3d 
were doing more than merely rendering assistance - they were active participants in a scheme to defraud. ${ }^{163}$ The poor reasoning by the Stoneridge majority - that fraud calculated to mislead the certifying accountants was too remote to meet $\S 10(\mathrm{~b})$ 's reliance requirementappears to be driven by the eagerness to create what the majority incorrectly perceives as a "pro-business" rule to discourage litigation. ${ }^{164}$

The recent frauds in the "pro-business" environment have greatly damaged confidence in the market. ${ }^{165}$ The value of stock has fallen immensely and businesses find it expensive or impossible to raise capital. ${ }^{166}$ Even though Stoneridge could have been decided without considering aiding and abetting claims, I argue that the remedy is to expressly provide for aiding and abetting liability in order to deter unethical business practices and restore confidence in our financial markets.

An interesting hypothetical reveals the fragile nature of the majority's analysis. Suppose that Scientific-Atlanta and Motorola did not help inflate the revenues of an unhealthy company. ${ }^{167}$ Suppose instead that they had engaged a healthy firm in sham transactions to understate profits. Suppose that all parties involved purchased stock at the resulting depressed price, and then issued corrected financial statements showing the accurate and higher profits, selling the stock that had been acquired at depressed prices for a handsome profit. In this case the defendants would be liable under the majority analysis because they would have received their compensation in the act of buying securities directly from stockholders. Nevertheless, their actual wrongful conduct that created the harm to the shareholders was the fraud in the product market calculated to mislead auditors, analysts, and investors about the

1041 (9th Cir. 2008)

163. Simpson, 452 F.3d at 1049.

164. Cf. Stoneridge, $128 \mathrm{~S}$. Ct. at 771 ("[Section] 10(b) ... should not be interpreted to provide a private cause of action against the entire marketplace in which the issuing corporation operates.").

165. See Eric Lipton and Ron Nixon, A Bank With Its Own Woes Lends Only a Trickle of Bailout, N.Y. TIMES, Jan. 14, 2009, at A1 (quoting the Treasury official in charge of the TARP bailout program to say that "[w]e're still in a period of fairly low confidence").

166. David E. Sanger, U.S. Bank And Trust?, N.Y. TIMES, Jan. 26, 2009, at A1 (reporting that large financial institutions are finding it very difficult to raise the capital needed to continue operating).

167. Charter Communications is the fourth largest cable company in the United States and a Fortune 500 firm. Charter, About Charter, http://www.charter.com/Visitors/AboutCharter .aspx?NonProductItem $=20$. Nevertheless, its debt is rated CCC and its stock traded for three cents per share on February 20, 2009-a drop from more than twenty-three dollars per share in July of 2001 before the scam became known. Yahoo! Finance, Charter Communications Inc., http:// finance.yahoo.com/q? =CHTRQ.PK (follow the "max" hyperlink under the chart on the right side of the screen) (last visited Oct. 7, 2009). It is not a financially healthy corporation. 
value of the securities. The fact that the Stoneridge defendants took the fruits of their fraud in the form of sustaining a profitable relationship with a financially unhealthy business gives rise to the majority's justification for calling this an ordinary business transaction that immunizes the vendor-customers from liability under the federal securities laws. This is a substance-trumps-form result that counters Congress's intent when it crafted the federal securities laws. Under a law that expressly allows investors to bring claims against aiding and abetting violations of $\S 10(\mathrm{~b})$, the unethical substantive conduct would be deterred regardless of which form it takes.

Presumably the majority's desire to obtain this result is driven by a good-faith belief that lawsuits are bad for business and the economy, but the fact of the matter is that fraud is worse for business. ${ }^{168}$ Economic theory drives much of the conservative branch of the federal judiciary's reasoning. ${ }^{169}$ For example, Judge Easterbrook and Judge Posner are known for their use of economics, and are also widely viewed as conservative. ${ }^{170}$ But economic theory is full of examples of market failures and recommendations for government and legal intervention. ${ }^{171}$ Markets susceptible to fraud make one of the most compelling justifications for intervention under economic theory. ${ }^{172}$ The remedy

168. See Lynn A. Stout, Type I Error, Type II Error, and the Private Securities Litigation Reform Act, 38 ARIZ. L. REV. 711, 713 (1996) ("Because fraud turns the securities market into a 'market for lemons,' there is a consensus in the securities field that fraud is bad.").

169. See, e.g., Robert C. Ellickson, The Market for Social Norms, 3 AM. L. \& ECON. ReV. 1, 1 (2001) ("[M]y thesis is that the basic tools of microeconomics can illuminate social phenomena that traditionally have not been subjects of economic inquiry. Economists have developed analytic tools of unmatched power for dealing with the consequences of differences among individuals (and firms)."); Lawrence E. Mitchell, On the Direct Election of CEOs, 32 OHIO N.U. L. REv. 261, 262 n.10 (2006) (at least partly attributing the rise and dominance of law and economics analysis to the conservative political movement that began with the 1980 election of Ronald Reagan); Robert A. Prentice, The Case of the Irrational Auditor: A Behavioral Insight Into Securities Fraud Litigation, 95 Nw. U. L. REV. 133, 133 (2001) ("For more than two decades, the economic theory embodied in the law and economics movement has been the ascendant paradigm in legal analysis ....").

170. See, e.g., Robert A. Prentice, Chicago Man, K-T Man, and the Future of Behavioral Law and Economics, 56 VAND. L. REV. 1663, 1773 n.578 (2003) (suggesting that Circuit Court Judges Easterbrook and Posner are part of a widespread conservative movement developed by Henry Manne with corporate and conservative foundation support).

171. Cf. Richard W. Tresch, Public Finance: A Normative Theory 4 (1981) ("[T] he competitive market economy is seen as the ideal economic system, so much so that competitive market failure is a necessary condition for public sector activity.").

172. See Cross \& Prentice, supra note 137, at 338-39. Professors Cross and Prentice give a lucid explanation of the economic problem:

The basic economic problem is how to control the investment risk so that investors will be willing to risk their funds. Solving or ameliorating this problem is of enormous social value. Absent a solution, many investors will choose not to play the game at all, while others will discount the securities they purchase to take into account the increased risk of loss. 
provided by economic theory is to reduce information asymmetry by providing incentives for full and fair disclosure. ${ }^{173}$ Expansion of liability for aiding and abetting securities fraud provides the appropriate remedy - a market-based incentive structure. ${ }^{174}$

The result of the Court's holding creates moral hazard, whereby economic incentives to behave ethically are removed and positive economic incentives to engage in unethical conduct are created. ${ }^{175}$ This leads to economic inefficiency, which means that society's resources are allocated in a wasteful manner. ${ }^{176}$ People will not put their savings to the best possible use because credit markets and trust break down. ${ }^{177}$

This scheme is inherently inconsistent with the long-established and undisputed fact that Congress enacted the securities laws to protect the integrity of the financial markets. ${ }^{178}$ An analysis that allows perpetrators such as Scientific-Atlanta and Motorola to profit from their fraud (by collecting revenue from Charter longer than they otherwise could have) and escape liability under securities laws by classifying their actions as being limited to the product markets is based on a fairytale theory in which markets are disconnected. Public policy arguments, Congressional intent, and common sense all lead to the same conclusion: the Court's result is flawed and the contorted reasoning used to attain the result only illuminates the flaws, and these flaws have consequences.

\footnotetext{
Blind trust is not much of a solution, as managers face great temptations of opportunism. Id. (footnote omitted).

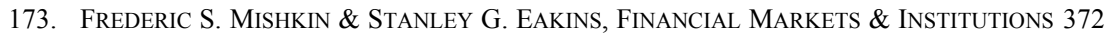
(6th ed. 2009) ("The solution ... is to eliminate asymmetric information by furnishing the people supplying funds with full details about the individuals or firms seeking to finance their investment activities.").

174. See Klock, Fortune Tellers, supra note 19, at 105 (expanding liability improves disclosure incentives and limiting liability weakens them).

175. See Cross \& Prentice, supra note 137, at 336 ("Andy Fastow, Bernie Ebbers, Ken Lay, Jeff Skilling, Jack Grubman, Henry Blodgett, Richard Scrushy, Dennis Kozlowski, Mark Swartz, Richard Causey and so many others decided to forfeit their reputations in exchange for short-term lucre....").

176. Mark Klock, Are Wastefulness and Flamboyance Really Virtues? Use and Abuse of Economic Analysis, 71 U. CIN. L. REV. 181, 198 (2003).

177. See George A. Akerlof, Behavioral Macroeconomics and Macroeconomic Behavior, 92 AM. ECON. REV. 411, 413 (2002) ("The failure of credit markets is one of the major reasons for underdevelopment.") [hereinafter Akerlof, Macroeconomic Behavior].

178. See SteInBERG, supra note 94, at 523 ("Generally, the antifraud provisions of the securities acts were designed to protect investors, to assure fair-dealing in the securities markets, and to promote ethical business practices.").
} 


\section{FORUM SHOPPING: SECONDARY LIABILITY IN STATE COURTS}

The Stoneridge decision will result in an increase in forum shopping as securities fraud plaintiffs looking for viable legal theories to reach culpable deep pockets are forced to plead cases involving this basic fact pattern as aiding and abetting a breach of fiduciary duty. ${ }^{179}$ Unlike standard tort principles under common law, Stoneridge has built a flawed concept of duty into the federal securities laws, and certainly into $\S 10(\mathrm{~b})$ and Rule 10b-5. The majority's decision asserts that parties that owe no duty to shareholders cannot be liable for deceptive conduct that ultimately harms shareholders as long as there is no direct connection. ${ }^{180}$ Under the Court's analysis there is no direct connection sufficient to establish reliance when the deceptive conduct takes place in the product market and the participants do not communicate directly with the shareholders. ${ }^{181}$

Under standard negligence analysis, one who does not owe a duty need not act to save a drowning victim. ${ }^{182}$ But a duty can be created by misconduct. ${ }^{183}$ If $A$ pushes $B$ into a pool, $A$ has a duty to rescue $B$ if $B$ begins to drown. ${ }^{184}$ This analogy is not quite applicable in Stoneridge because Scientific-Atlanta and Motorola did not prepare and disseminate the false financial statements. ${ }^{185}$ The appropriate analogy would be one where $A$ knowingly sets into place a chain of events that he could foresee would cause $B$ to fall in the water. Under standard negligence analysis, $A$ would still have a duty to rescue $B$ resulting from $A$ 's misconduct. ${ }^{186}$ This hypothetical is in fact analogous to what Scientific-Atlanta and Motorola actually did, with a profit motivation thrown in. Indeed, Professor Prentice has also highlighted this flaw in the majority's reasoning, pointing out that the majority failed to ask two related but

179. See Klock, Fiduciary Duty, supra note 11, at 45 (observing that increased difficulty in bringing federal securities claims will move plaintiffs to plead breach of fiduciary duty against Delaware corporations and their aiders and abettors).

180. Stoneridge Inv. Partners, LLC v. Scientific-Atlanta, Inc., 128 S. Ct. 761, 769 (2008).

181. Id.

182. See Restatement (SECOND) OF TORTS $\S 314 \mathrm{cmt}$. c (1965) ("The origin of the rule lay in the early common law distinction between action and inaction, or 'misfeasance' and 'nonfeasance."').

183. See Klock, Fiduciary Duty, supra note 11, at 18.

184. Id. ("While directors might not be obliged to give information absent special circumstances, neither can they push the shareholders into a pool of false information and watch without liability. This ... suggests that directors have a duty not to deceive shareholders because such deception constitutes an interference with shareholder rights.").

185. Stoneridge, $128 \mathrm{~S}$. Ct. at 767.

186. Sinai, supra note 6 , at $183-84$ (" $[\mathrm{I}] \mathrm{t}$ is clear that if some scheme would defraud a specific foreseeable group, then this ought to create the duty to such group: a duty not to defraud."). 
distinct questions. The majority asked only whether the plaintiffs relied on the defendants' acts, which of course they did not because they were unaware of the deceptive conduct in the product market - that is what made the fraud a profitable opportunity. ${ }^{187}$ But the correct questions were: did the investors "rely on deceptive statements" and were "the defendants legally responsible for those deceptive statements?"188 The answer to both questions should have been yes; ${ }^{189}$ just as $A$ would be liable for $B$ 's drowning if $A$ knowingly set into place events that foreseeably caused $B$ to fall into deep water.

Unfortunately, in light of Stoneridge, this conduct is not actionable under the federal securities laws until Congress enacts a remedy. ${ }^{190}$ However, under Malone and O'Malley, the conduct is clearly actionable under Delaware law. ${ }^{191}$ Even where there is no duty to disclose, directors and officers breach their fiduciary duty to shareholders when they communicate misinformation to their shareholders. ${ }^{192}$ Aiding and abetting a breach of fiduciary duty is actionable under Delaware law. ${ }^{193}$ Given that Charter and Motorola are Delaware corporations, it is unfortunate for the plaintiffs that the action was not filed in Delaware courts under the alternate theory.

The resulting incentive to bring securities class actions to the more favorable forum of Delaware does not lead to a uniform policy for protecting the integrity of the national market. If investors cannot be confident that the financial statements released are not fraudulent, and if investors know that the solvent individuals who profit from fraud might be insulated from liability, then investors must seriously consider the state in which corporations are incorporated before purchasing stocks. ${ }^{194}$ Although the viability of obtaining compensation for corporate wrongdoing in Delaware and some other state courts is beneficial for the unfortunate victims that can bring such claims, it is clearly a poor model

\footnotetext{
187. Prentice, supra note 9 , at 652.

188. Id. at 653 .

189. Id.

190. Stoneridge, $128 \mathrm{~S}$. Ct. at 774.

191. O’Malley v. Boris, 742 A.2d 845, 850 (Del. 1999); Malone v. Brincat, 722 A.2d 5, 14 (Del. 1998); see Klock, Fiduciary Duty, supra note 11, at 44-45 (concluding that Malone and O'Malley provide authority for defrauded investors to bring claims in Delaware based on aiding and abetting).

192. Malone, 722 A.2d at 14 .

193. See id. (holding that a claim of aiding and abetting a breach of duty could be articulated on the facts).

194. $C f$. Roberta Romano, The Genius of American Corporate LaW 16-18 (1993) (citing empirical studies showing that investors weigh the terms of corporate governance before purchasing stocks).
} 
for regulation of what is undeniably a national market. ${ }^{195}$ Furthermore, Congress clearly sought to limit forum shopping when it enacted the Securities Litigation Uniform Standards Act of 1998 (SLUSA). ${ }^{196}$

SLUSA was designed to prevent investors from bringing securities claims into state courts and avoid the procedural hurdles erected under the PSLRA. ${ }^{197}$ However, SLUSA contained a provision commonly known as the "Delaware carve-out," which exempted claims based on a breach of fiduciary duty under state law. ${ }^{198}$ In light of this provision, the necessary conclusion that Stoneridge will result in more forum shopping must certainly be another unintended consequence of the poorly reasoned decision. The forum-shopping consequence only adds to the need for aiding and abetting liability.

\section{The NeEd For Aiding AND ABEtTING LiAbILITY IN PRIVATE ACTIONS}

\section{A. Economic Theory Justifies Aiding and Abetting Liability}

The unfortunate facts are that Central Bank and Stoneridge violate the Court's own precedents and create highly contrived distinctions to reach a result that is probably motivated by good intentions but based on an unrealistic premise, and they are causing more harm than good. For example, in Bateman Eichler, Hill Richards Inc. v. Berner, ${ }^{199}$ the Court

195. See Elizabeth F. Brown, The Tyranny of the Multitude Is a Multiplied Tyranny: Is the United States Financial Regulatory Structure Undermining U.S. Competitiveness?, 2 BRooK. J. CORP. FIN. \& COM. L. 369, 377 (2008) ("[R]egulatory structures that rely on multiple regulators, such as the United States, may overregulate when compared to structures that use a single regulator because multiple regulators produce overlapping and conflicting regulations."); James D. Cox, Regulatory Duopoly in U.S. Securities Markets, 99 ColuM. L. Rev. 1200, 1244 (1999) ("Thus, the history of the blue sky laws dramatically documents that the natural tendency of state regulatory competition is a race to the bottom. We find not only a weak interest among the states to impose disclosure demands greater than those of the SEC, but also that in those instances in which a state's restrictions are a burden, the issuer's tendency is to shop for a less demanding state where its offering can occur. Certainly this is not a record to suggest that the states will have a balanced view toward the needs of investors and issuers. Their own history illustrates that competition for offerings has caused a weakening and not a strengthening of securities regulation standards."); Karmel, supra note 12 , at 544

196. See Securities Litigation Uniform Standards Act of 1998, Pub. L. No. 105-353, 112 Stat. 3227 (1998) (codified in scattered sections of 15 U.S.C.).

197. See Richard H. Walker \& J. Gordon Seymour, Recent Judicial and Legislative Developments Affecting the Private Securities Fraud Class Action, 40 ARIZ. L. REV. 1003, 1028 (1998) ("Scarcely had the ink dried on the Reform Act when the new congressional proposals ... to preempt state securities fraud lawsuits began to emerge.").

198. Klock, Fiduciary Duty, supra note 11, at 16 n.114.

199. 472 U.S. 299 (1985). 
rejected, for the purposes of determining the availability of the equitable in pari delicto defense under the securities laws, attempts to distinguish between express and implied causes of action. ${ }^{200}$ Further, the Court found private causes of action to be an important tool, stating that "we repeatedly have emphasized that implied private actions provide 'a most effective weapon in the enforcement' of the securities laws and are 'a necessary supplement to Commission action.' In addition, we have eschewed rigid common-law barriers in construing the securities laws."201 In other cases, the Court has held that remedies under the securities laws are cumulative and not less than common law remedies, that Congress's intent in passing the securities laws was to protect the investing public, and that the Court will not find interpretations that frustrate this intent. ${ }^{202}$ Obviously Central Bank moved away from these attitudes, but Stoneridge has gone much further-Central Bank merely involved a negligent defendant, not willing and active participants to the fraud as in Stoneridge. ${ }^{203}$

There is a superficially reasonable argument for the proposition that securities litigation causes more harm than good. The argument is that the entire economy bears the costs of the litigation. ${ }^{204}$ This is a cynical view that implicitly assumes that lawyers will always be quick to bring meritless suits and that corporate officers' conduct and ethical behavior will not respond to economic incentives. ${ }^{205}$ As long as the liability rules protect unethical conduct, unethical conduct that is profitable will be widespread. ${ }^{206}$ But if the liability rules governing the market are changed to punish unethical conduct, the amount of unethical conduct will decrease. $^{207}$ Economic theory predicts that decision-makers respond to

\footnotetext{
200. Id. at 309-10.

201. Id. at 310 (citations omitted).

202. Herman \& MacLean v. Huddleston, 459 U.S. 375, 386-87 (1983).

203. Stoneridge Inv. Partners, LLC v. Scientific-Atlanta, Inc., 128 S. Ct. 761, 775 (2008) (Stevens, J., dissenting) (contrasting the Stoneridge facts with those of Central Bank).

204. See, e.g., Ralph K. Winter, Paying Lawyers, Empowering Prosecutors, and Protecting Managers: Raising the Cost of Capital in America, 42 DuKE L.J. 945, 976 (1993) (concluding that securities litigation raises the cost of capital).

205. Cf. Prentice, supra note 9, at 664. Professor Prentice reaches the logical conclusion that The majority faction's argument can sound persuasive only to those who either assume that all federal securities lawsuits are spurious or who believe that the legal system cannot ever distinguish between a valid claim and a specious claim. The majority faction's policy preferences seem to be only just below the surface in this reasoning. Id.

206. See Klock, Fortune Tellers, supra note 19, at 106 (changing liability rules will promote more ethical conduct).

207. Robert A. Prentice, Locating that "Indistinct" and "Virtually Nonexistent" Line Between Primary and Secondary Liability Under Section 10(b), 75 N.C. L. REV. 691, 778-79 (1997)
} 
incentives. $^{208}$ Moreover, changing the relative costs of different activities will affect the choices made by decision-makers. ${ }^{209}$ Private actions against corporations involved in fraud can save more than they cost through the deterrent effect in reducing fraud. Less fraud will allow all corporations to obtain capital at a lower cost from confident investors. ${ }^{210}$ The New York Stock Exchange, NASDAQ, and all other trade associations that represent large corporations should be lobbying Congress to amend the securities laws to provide for a private cause of action for aiding and abetting violations of $\S 10(\mathrm{~b}){ }^{211}$

There is a very good reason why a scheme of secondary liability is essential for rebuilding and maintaining the integrity of financial markets. If players in financial markets are always given the benefit of the doubt when they engage in questionable activities which are not clearly illegal, then financial market participants are effectively being encouraged with economic incentives to engage in shady conduct. ${ }^{212}$ This is effectively the well-known moral hazard problem that was rigorously explored by the Nobel Prize-winning economist Kenneth Arrow and is a principal topic in the insurance field. Moral hazard exists when people are encouraged to engage in undesirable behavior because they are insulated from its consequences. ${ }^{213}$ For example, a homeowner who does not take precautions against fire and even engages in

("Setting broad parameters of liability should reduce fraud, increase fairness, improve the accuracy of financial reporting, and, thereby, improve the efficiency of our financial markets consonant with the goals established by Congress for the 1934 Act." (footnotes omitted)).

208. See Stiglitz, supra note 160, at 32 (stating that "incentives are at the heart of modern economics").

209. Id. at 181 .

210. See Cross \& Prentice, supra note 137, at 337 ("Investors inevitably face a risk by handing their money over to be managed by others, as their resources may be lost through theft or mismanagement .... [E]fforts to address this risk short of securities law have failed.").

211. Consider what a leading finance professor wrote in his best-selling textbook in a prominently highlighted and set-off paragraph captioned "IMPORTANT":

Investors would not be willing to provide capital at favorable terms if they are not well protected. The entrepreneur ultimately internalizes any potential future failures caused by an inadequate corporate design today. Thus, to raise money on good terms in the first place, entrepreneurs want to design the firm and its governance structure so that investors will be protected.

WELCH, supra note 87 , at 898 .

212. See Sinai, supra note 6, at 187 (observing that, under the Supreme Court's current view, professionals can profit from fraud provided they exercise care to avoid public statements in the market).

213. See 2 KenNeth J. ARrow, The Organization of Economic Activity: Issues Pertinent to the Choice of Market Versus Nonmarket Allocation, in COLLECTED PAPERS OF KenNETH J. ARROW: GeNeral EQUilibrium 133, 142-44 (1983) [hereinafter ARROW, Economic Activity] (defining moral hazard). 
hazardous activities because he is fully insured. ${ }^{214}$ Or, a driver who is reckless because he has too many safety devices to suffer serious injury and is fully insured against property and liability losses. ${ }^{215}$ Insurance companies mitigate the effects of moral hazard through, among other things, the use of deductibles, which make the customers less than fully insured. ${ }^{216}$ The moral hazard now has its place in the securities markets, thanks to the protection from liability granted by Stoneridge. ${ }^{217}$

The economic and legal policy problems that result from this decision can be considered in depth after examining the words of Professor Arrow. He classified this as a problem of "confounding risks and decisions," ${ }^{218}$ and observed that the problem is applicable to a wide range of contexts:

In fact, it is not a mere empirical accident that not all the contingent markets needed for efficiency exist, but a necessary fact with deep implications for the workings and structure of economic institutions.... The very existence of insurance will change individual behavior in the direction of less care in avoiding risks. The insurance policy that would be called for by an optimal allocation of risk bearing would only cover unavoidable risks and would distinguish their effects from those due to behavior of the individual. But in fact all the insurer can observe is a result, for example, a fire or the success or failure of a business, and he cannot decompose it into exogenous and endogenous components. Contingent contracts, to speak generally, can be written only on mutually observed events, not on aspects of the state of the world which may be known to one but not both of the parties. ${ }^{219}$

My point, using Arrow's terminology, is that Stoneridge insulates wrongdoers by shielding them from the avoidable risks created by their decisions. Charter's investors obviously could not write a contract with Charter's suppliers to cover the risks of fraud perpetrated by such suppliers, and therefore the investors need the legal system to provide

214. See 2 Kenneth J. ARrow, General Economic Equilibrium: Purpose, Analytic Techniques, Collective Choice, in COLleCted PAPERS OF KENNETH J. ARROW: GENERAL EQUilibrium 199, 222 (1983) [hereinafter ARROW, Economic Equilibrium] (explaining moral hazard in the context of insurance).

215. See Elisabeth M. Landes, Insurance, Liability, and Accidents: A Theoretical and Empirical Investigation of the Effect of No-Fault Accidents, 25 J.L. \& ECON. 49, 59-64 (1982) (examining empirical evidence of higher accident mortality rates in states that have switched to no-fault insurance schemes).

216. MISHKIN \& EAKINS, supra note 173, at 577 .

217. See Stoneridge Inv. Partners, LLC v. Scientific-Atlanta, Inc., 128 S. Ct. 761, 778 (2008) (Stevens, J., dissenting) (referring to the majority opinion as immunizing an undefined class of defendants against liability).

218. ARROW, Economic Activity, supra note 213, at 143.

219. ARROW, Economic Equilibrium, supra note 214, at 222. 
protection. $^{220}$ If Scientific-Atlanta and Motorola were held liable for their actions, the moral hazard problem and the resulting economic inefficiency would vanish. However, we cannot afford to wait for another case and a more economically sophisticated Court. We need legislation that expressly puts unethical corporate officers and others on notice that they will be liable to victims for these risk-creating decisions. ${ }^{221}$ Placing the risk of the decision on the decision-maker is the way to restore efficiency and confidence to the market. ${ }^{222}$

The improved ethical standards that would result from an application of aiding and abetting liability can be illustrated with a simple examination of how the statutory scheme works in cases of primary liability under the 1933 Act. $^{223}$ The Act prohibits the sale of securities in the public market unless the securities have been registered, ${ }^{224}$ and the registration statement must contain all material facts. ${ }^{225}$ Economic incentives to comply with $\S 77 \mathrm{e}$ are given by $\S 77 l$, which states the consequences for either failure to register securities sold in the public market or omission of a material fact. ${ }^{226}$ The consequences are strict liability for losses by all purchasers without any requirement for reliance or causation. ${ }^{227}$ Suppose it is questionable as to whether the securities are sold in the public market. Liability can be avoided by adhering to the requirements of the safe harbors for private placements promulgated by the SEC. ${ }^{228}$ If an issuer does not avail himself of the safe harbor rules and sells securities without registering them, then he can expect that at a minimum he will incur substantial costs down the road litigating the question as to whether the offering was public. Suppose it is questionable as to whether a fact is material. If it can be argued either

220. This need must be filled by statute. Roberta Romano, The States as a Laboratory: Legal Innovation and State Competition for Corporate Charters, 23 YALE J. ON REG. 209, 212 (2006) ("Corporation codes consist of default rules that supply standard contract terms for corporate governance where the parties fail to specify alternative arrangements.").

221. See Levin, supra note 29 (calling on Congress to overturn Stoneridge to prevent continued unfairness to investors).

222. See R. Link Newcomb, Note, The Limitation of Directors' Liability: A Proposal For Legislative Reform, 66 TEX. L. REV. 411, 433 (1988) ("Placing the burden of risk upon decision makers both compensates shareholders for their losses and serves to deter directors from careless decision making.").

223. Securities Act of 1933, 15 U.S.C. § 77a-77aa (2006).

224. $\$ 77 \mathrm{e}$.

225. $\S 77 \mathrm{k}$

226. § 771 .

227. Id.

228. See John L. Orcutt, Improving the Efficiency of the Angel Finance Market: A Proposal to Expand the Intermediary Role of Finders in the Private Capital Raising Setting, 37 ARIz. ST. L.J. 861, 933 (2005) (describing the safe harbor of SEC Rule 506). 
way, then the prudent course of action is to include the fact in the registration statement and avoid litigation. ${ }^{229}$ The system deters shady behavior operating in an ethical gray zone.

This system of strict liability for less than full disclosure promotes ethical behavior. A system of secondary liability for aiding and abetting fraud would also promote ethical conduct and enhance investor protection and confidence in the market. If it is unclear as to whether assisting a violation of securities laws is wrong, then imposing liability will discourage shady and questionable conduct. A rule that allows everything except that which is not expressly prohibited encourages excessive unethical behavior and will drive capital out of the market. This concept was advanced by Nobel Prize-winning economist George Akerlof in his classic article on market breakdowns in the absence of trust:

Informal unwritten guarantees are preconditions for trade and production. Where these guarantees are indefinite, business will suffer .... [T] he difficulty of distinguishing good quality from bad is inherent in the business world; this may indeed explain many economic institutions and may in fact be one of the more important aspects of uncertainty.

Professor Akerlof was the first to carefully explain how quality differentials in the presence of information asymmetry affects markets. ${ }^{231}$ He observed that the absence of integrity in the credit markets of less developed countries is critical to understanding why such countries continue to remain less developed. ${ }^{232} \mathrm{He}$ also commented that institutions can sometimes develop to counteract the problems caused by information asymmetry. ${ }^{233}$ I suggest that a regulatory framework that provides private civil liability for aiding and abetting fraud in the financial markets would go far toward increasing trust in the marketplace and reducing the economic costs of dishonesty. The costs of dishonesty are clearly explained:

229. See Carl W. Schneider et al., Going Public: Practice, Procedure, and Consequences, 27 VILL. L. REV. 1, 14 (1982) ("[T]he prospectus is a disclosure document, an insurance policy against liability. With the view toward protection against liability, there is a tendency to resolve all doubts against the company and to make things look as bleak as possible.").

230. George A. Akerlof, The Market for "Lemons": Quality Uncertainty and the Market Mechanism, 84 Q. J. ECON. 488, 500 (1970) [hereinafter Akerlof, "Lemons"].

231. See MishKIN \& EAKINS, supra note 173, at 371 (describing the importance and fame of this scholarship).

232. Akerlof, "Lemons", supra note 230, at 497-99.

233. Id. at $499-500$. 
Consider a market in which goods are sold honestly or dishonestly; quality may be represented, or it may be misrepresented. The purchaser's problem, of course, is to identify quality. The presence of people in the market who are willing to offer inferior goods tends to drive the market out of existence.... It is this possibility that represents the major costs of dishonesty - for dishonest dealings tend to drive honest dealings out of the market. There may be potential buyers of good quality products and there may be potential sellers of such products in the appropriate price range; however, the presence of people who wish to pawn bad wares as good wares tends to drive out the legitimate business. The cost of dishonesty, therefore, lies not only in the amount by which the purchaser is cheated; the cost also must include the loss incurred from driving legitimate business out of existence. $^{234}$

In accepting his Nobel Prize more than thirty years later, Professor Akerlof wrote, "In some markets, asymmetric information is fairly easily soluble by repeat sale and by reputation. In other markets, such as insurance markets, credit markets, and the market for labor, asymmetric information between buyers and sellers is not easily soluble and results in serious market breakdowns." 235

In financial markets, the cost of dishonesty is particularly severe. ${ }^{236}$ It drives capital out of the market, which increases the cost of what scarce little capital remains. ${ }^{237}$ Investment becomes unprofitable, growth stops, and the economy slides further, taking jobs with it. ${ }^{238}$ Another Nobel Prize winner, Joseph Stiglitz, explained that it only takes a small amount of information asymmetry to create a substantial effect. ${ }^{239}$ "Talk is cheap" and, therefore, not credible. ${ }^{240}$ If a firm has no credible way to communicate to the public that its financial records are not based on sham transactions with businesses that are immune from liability, then

234. Id. at 495 .

235. Akerlof, Macroeconomic Behavior, supra note 177, at 413.

236. See MishKIN \& EAKINS, supra note 173 at 29 ("The problems created by adverse selection and moral hazard are an important impediment to well-functioning financial markets.").

237. See Ronald J. Colombo, Ownership, Limited: Reconciling Traditional and Progressive Corporate Law via an Aristotelian Understanding of Ownership, 34 J. CORP. L. 247, 281 (2008) (suggesting that corporate directors' wrongdoing precipitates a flight of capital from the markets).

238. See Steven L. Schwarcz, Systematic Risk, 97 GEO. L.J. 193, 214 (2008) ("Investors lose confidence and begin withdrawing their money from the remaining capital markets, weakening those markets and - due to a perception, if not reality, of heightened default risk-leading to a significant widening of credit spreads and a resulting higher cost of capital. In a vicious cycle, the increased cost of capital triggers defaults and also causes further liquidations of positions (to generate cash) and thus, more price-drops.").

239. Joseph E. Stiglitz, Information and the Change in the Paradigm in Economics, 92 AM. ECON. REV. 460, 461 (2002).

240. Id. at 471 . 
our markets are in deep trouble. ${ }^{241}$ But our markets could be saved if we have the will to impose private liability for aiding and abetting fraud.

The theory of regulation is rooted in economics. ${ }^{242}$ The public choice field uses the tools of economics to analyze politics, ${ }^{243}$ and shows that optimal regulation involves a balance between the marginal benefit and marginal harm of the rule. ${ }^{244}$ Where markets function perfectly, there is no benefit to regulation, there is only the potential for harm. Where some type of market problem such as asymmetric information or moral hazard exists, there is the potential for designing regulation to improve the functioning of the market. ${ }^{245}$

Regulation is typically desired in the event of a market failure. The literature of information economics has taught that, "[u]nder the imperfect information paradigm, markets are almost never Pareto efficient." ${ }^{246}$ In other words, regulation is required to make securities markets efficient.

Optimal regulation should provide the maximum benefit at minimum cost. Sometimes bright-line rules are optimal; sometimes they are not. After the Enron fraud became public, I argued:

$[P]$ recise rules can have the effect of encouraging everyone to operate in the ethical gray zone. The expressed minimum standard of conduct becomes acceptable. What is not expressly prohibited becomes ethical. Conversely, a rule imposing liability for less than full and fair disclosure should lead to disclosure in questionable matters.

241. See Klock, Fortune Tellers, supra note 19, at 105 ("The reduction in liability risk for auditors after Central Bank may have drastically reduced the value of audits and impaired the markets.").

242. See generally Sam Peltzman, Toward a More General Theory of Regulation, 19 J.L. \& ECON. 211 (1976) (extending the theory of regulation); $c f$. Henry G. Manne, Insider Trading and the Law Professors, 23 VAND. L. REV. 547, 549 (1970) (“[M]oral arguments are frequently either sham or a refuge for the intellectually bankrupt.").

243. Dennis C. Mueller, Public Choice II 1 (1989) ("Public choice can be defined as the economic study of nonmarket decision making, or simply the application of economics to political science.").

244. See Richard L. Revesz, Environmental Regulation, Cost-Benefit Analysis, and the Discounting of Human Lives, 99 COLUM. L. REV. 941, 943 (1999) (observing that regulation is frequently conducted using cost-benefit analysis).

245. See STIGLitZ, supra note 160, at 153 ("When there is a market failure, government may be able to correct the market failure and enhance the economy's efficiency.").

246. Stiglitz, supra note 239, at 468. "Pareto efficiency" occurs when the allocation of resources is such that "no one can be made better off without making somebody else worse off." STIGLITZ, supra note 160 , at 320 .

247. Klock, Fortune Tellers, supra note 19, at 106. 
Legislation providing liability for assisting violations of the federal securities laws and making the remedy available in private actions will result in a higher standard of conduct in the corporate world. This is an objective which has been sought for years. ${ }^{248}$

\section{B. Case Study: Enron and Merrill Lynch}

As an example of the serious magnitude of the problem of diminished liability for fraud, we only need to look at Enron Corporation. Enron's massive fraud was aided by many financial market players, including financial giant Merrill Lynch. ${ }^{249}$ Merrill was not held liable for its role in the collapse ${ }^{250}$ but not because of favorable facts and presumptions. $^{251}$ To the contrary; Merrill escaped liability because the law, as interpreted by the courts, does not extend to aiders and abettors and because participants in a fraud who do not directly communicate with the market are no more than aiders and abettors. ${ }^{252}$

In Regents of the University of California v. Credit Suisse First Boston (USA), Inc. it was revealed that Merrill Lynch had actively planned to help prolong Enron's fraud by assisting the company in moving toxic assets off the books and making a large loan appear to be

248. Id. at 105 ("The reduction in liability risk for auditors after Central Bank may have drastically reduced the value of audits and impaired the markets. This impairment of the markets is where attention should be focused. The original philosophy of full and fair disclosure, and the historical development of implied private rights of action and aiding and abetting liability fostered the growth of our capital markets into the envy of the world. It was a mistake to depart from that regime, and it is time to return to it.").

249. Regents of the Univ. of Cal. v. Credit Suisse First Boston (USA), Inc., 482 F.3d 372, 377 (5th Cir. 2007), cert. denied, 128 S. Ct. 1120 (2008); see also KURT EICHENWALD, CONSPIRACY OF FOOLS 293-96 (2005) (documenting various transactions and participants that helped to facilitate Enron's collapse).

250. David G. Savage, High Court Rejects Investors' Suit Against Enron Bankers, L.A. TIMES, Jan. 23, 2008, at C3.

251. See Credit Suisse, 482 F.3d at 393 ("We have applied the Supreme Court's guidance in ascribing a limited interpretation to the words of $\S 10$, viewing the statute at the result of Congress's balancing of competing desires to provide for some remedy for securities fraud without opening the floodgates for nearly unlimited and frequently unpredictable liability for secondary actors in the securities markets.").

252. Id. ("We recognize, however, that our ruling on legal merit may not coincide, particularly in the minds of aggrieved former Enron shareholders who have lost billions of dollars in a fraud they allege was aided and abetted by the defendants at bar, with notions of justice and fair play. We acknowledge that the courts' interpretation of $\S 10(\mathrm{~b})$ could have gone in a different direction and might have established liability for the actions the banks are alleged to have undertaken."); see also Stoneridge Inv. Partners, LLC v. Scientific-Atlanta, Inc., 128 S. Ct. 761, 769 (2008) (holding that reliance is presumed when stock statements become public). 
an infusion of equity. ${ }^{253}$ The Fifth Circuit Court of Appeals described one of these transactions:

For example, plaintiffs allege that Merrill Lynch engaged in what they dub the "Nigerian Barges Transaction." According to plaintiffs, Enron wanted to "sell" its interest in electricity-generating barges off the coast of Nigeria by the end of 1999 so that it could book revenue and meet stock analysts' estimates for the calendar quarter. It could find no legitimate buyer, so it contacted Merrill Lynch and guaranteed that it would buy the barges back within six months at a premium for Merrill Lynch.

Six months later, Enron made good on its guarantee; an Enroncontrolled partnership bought the barges from Merrill Lynch at a premium. When Enron reported its results for 1999, instead of booking the transaction as a loan, the characterization that Enron's outside accountants state would have been appropriate had they known of the side-agreement to buy back the barges, Enron booked the transaction as a sale and accordingly listed the revenue therefrom in its year-end financial statement.

Plaintiffs allege that the banks knew exactly why Enron was engaging in seemingly irrational transactions such as this. They cite certain of the banks' internal communications they characterize as proving that the banks were aware of the personal compensation Enron executives received as a result of inflating their stock price through the illusion of revenue and that the banks intended to profit by helping the executives maintain that illusion. ${ }^{25}$

Merrill Lynch was risky and engaged in unethical conduct. ${ }^{255}$ But the law, as created by the Supreme Court in Central Bank and its progeny, encouraged Merrill's actions. The Fifth Circuit found Merrill not liable; its conduct did not constitute a misrepresentation "on which an efficient market may be presumed to rely" and was not manipulative. $^{256}$ The unethical conduct by Merrill enabled Enron to continue its fraud for at least another year and ultimately increased the number of defrauded investors and the magnitude of losses that shocked the markets. ${ }^{257}$ Despite its egregious role in the Enron collapse, Merrill

253. Credit Suisse, 482 F.3d at 377.

254. Id.

255. See Bethany Mclean \& Peter Elkind, The Smartest Guys in the Room 208 (2003) (reporting that a Merrill executive noted concerns over the reputational risk of aiding and abetting Enron's income manipulation).

256. Credit Suisse, 482 F.3d at 390.

257. See id. at 377 (observing that the "Nigerian Barges Transaction" took place in 1999 and Enron collapsed in 2001). 
was legally protected from liability as the result of the Supreme Court's decisions. Ironically, Central Bank facilitated the size of the fraud perpetuated by Enron (with Merrill Lynch's assistance).

In Stoneridge, the Court had an opportunity to limit Central Bank's damage, but instead chose to enhance it. It is clear that the Stoneridge majority did not consider the conduct of Motorola and Scientific-Atlanta to be socially desirable. ${ }^{258}$ The PSLRA plainly makes aiding and abetting illegal. ${ }^{259}$ Moreover, the theory of scheme liability endorsed by the Ninth Circuit-holding willing and active participants in the fraud liable -is clearly consistent with the Supreme Court's holding in Central Bank. $^{260}$ Instead, the Court chose to use a sophomoric distinction between product markets and securities markets to conclude that no causal connection existed between the unethical corporate conduct and investor losses. ${ }^{261}$ This is breaking new ground and tramples investor rights more than ever before. ${ }^{262}$ The result is a transparent manifestation of the Court's hostility towards private litigation. ${ }^{263}$

The Court was clearly motivated by its desire to limit private rights of action under the securities laws because it believes that private enforcement causes more harm than good. ${ }^{264}$ The empirical facts do not support this belief. ${ }^{265}$ Moreover, the Court conveniently ignores the collateral damage caused by the moral hazard that it has created and nurtured. The alternative system of holding secondary participants who are a substantial factor in the wrongdoing liable will promote ethical

258. See Stoneridge Inv. Partners, LLC v. Scientific-Atlanta, Inc., 128 S. Ct. 761, 773 (2008) (noting that criminal penalties are a strong deterrent to this conduct).

259. 15 U.S.C. $\$ 78 \mathrm{t}(\mathrm{e})(2006)$.

260. See Stoneridge, 128 S. Ct. at 774-75 n.2 (Stevens, J., dissenting) (citing Brief of the Sec. \& Exch. Comm'n as Amicus Curiae Supporting Appellants at 21, Simpson v. AOL Time Warner Inc., 452 F.3d 1040 (9th Cir. 2006) (No. 04-55665), 2004 WL 5469571).

261. Supra note 151 and accompanying text.

262. Stoneridge, 128 S. Ct. at 776 (Stevens, J., dissenting) ("The Court's view of the causation required to demonstrate reliance is unwarranted and without precedent.").

263. See id. at 779 (citing the Court's "mistaken hostility" towards and continuing campaign to render private actions toothless); Prentice, supra note 9, at 677 ("So eager was the Stoneridge majority to put limits upon the right of fraud victims to obtain recompense that it cast aside this previously self-imposed restraint on the use of policy arguments and returned to the precedent of earlier cases that considered policy arguments.").

264. Stoneridge, $128 \mathrm{~S}$. Ct. at 772 (majority opinion) (suggesting that secondary liability would raise the costs of doing business).

265. See id. at 779 (Stevens, J., dissenting) ("But liability for those who violate $\S 10$ (b) 'will not harm American competitiveness; in fact, investor faith in the safety and integrity of our markets is their strength."') (citing Motion for Leave to File Brief Out of Time and Brief Amici Curiae of Former SEC Commissioners in Support of Petitioner at 9, Stoneridge Inv. Partners, LLC v. Scientific-Atlanta, Inc., 128 S. Ct. 761 (2008) (No. 06-43), 2007 WL 2065260). 
conduct in financial markets more than it will promote strike suits. ${ }^{266}$ The economic benefits will outweigh the economic costs. ${ }^{267}$

\section{The Importance of Promoting Market Efficiency}

Some recent commentary on Stoneridge has argued for adoption of the substantial participation standard and revitalization of scheme liability. ${ }^{268}$ Although these principles advance the integrity of the marketplace, their adoption by this Court has less chance of happening than the lottery being won by someone who does not play it. Although the fraud committed by the supporting characters can be fairly characterized as a primary violation of $\S 10(\mathrm{~b})$, as the dissenting Justices argued, a broader range of protection for the marketplace is needed in our current environment. Financial fraud has become a big-time growth industry. ${ }^{269}$ It is time to amend the federal securities laws to expressly provide for a private cause of action for aiding and abetting violations of $\S 10(\mathrm{~b})$ in order to protect investors and allow the market to function more efficiently.

In an efficient market investors can be confident that they will earn a fair rate of return on average. ${ }^{270}$ An efficient capital market also ensures entrepreneurs, small businesses, and corporations the ability to obtain necessary capital at the lowest possible cost. ${ }^{271}$ Efficient capital markets fuel economic growth. ${ }^{272}$ But when investors believe their expected

266. See id. at $778 \mathrm{n} .10$ ("The success of the U.S. securities markets is largely the result of a high level of investor confidence in the integrity and efficiency of our markets.") (citing S. REP. No. 104-98, p. 8 (1995), reprinted in 1995 U.S.C.C.A.N. 679, 687).

267. John Coffee, 'Regulation-Lite' Belongs to a Different Age, FIN. TIMES, Jan. 21, 2008, at 11 (observing that since deterrence works, cross-listed foreign companies realize a drop in their cost of capital when listing on the NYSE, but not when listing on the London Stock Exchange).

268. See Seth S. Gomm, See No Evil, Hear No Evil, Speak No Evil: Stoneridge Investment Partners, LLC v. Scientific-Atlanta, Inc. and the Supreme Court's Attempt to Determine the Issue of Scheme Liability, 61 ARK. L. REV. 453, 454 (2008) ("Although the current Court is unlikely to allow private scheme-liability actions in the near future, Congress may act in favor of shareholderplaintiffs when it sees the wisdom of allowing such § 10(b) actions.").

269. See, e.g., Zathrina Perez et al., Securities Fraud, 45 Am. Crim. L. ReV. 923, 991 (2008) (discussing the growing problem of online financial fraud).

270. See Klock, Mainstream Economics, supra note 114, at 306 ("In a fair game each investor's expected return is commensurate with his level of risk." (citation omitted)).

271. See John C. Coffee, Jr., Market Failure and the Economic Case for a Mandatory Disclosure System, 70 VA. L. REV. 717, 734 (1984) ("Depending on a firm's share price, its cost for obtaining capital will be either too high or low as compared to the cost that would prevail in a perfectly efficient market.").

272. See Coffee, supra note 267 at 11 (observing that our markets provide capital at low cost and the "lower cost of capital carries potential benefits for the broader society: namely, a higher gross domestic product and lower unemployment"). 
returns will be lower than what is actuarially fair, they will pull capital out. $^{273}$ The flight of capital results in diminished business investment, fewer jobs, less tax revenue to fund government programs, and more economic hardship. ${ }^{274}$ We should implement aiding and abetting liability not just to promote better ethical practices in the industry, but also to promote strong investor confidence and economic growth. ${ }^{275}$

The optimality of well-functioning economic markets is widely understood, ${ }^{276}$ and so is the disastrous effect that fraud can have on markets. ${ }^{277}$ We know the cure for fraud:

The beauty of the theoretical competitive market is that all problems are self-correcting. Unfortunately, reality is not as beautiful. The ideal competitive market takes all widgets as homogeneous. In reality, we have quality differentials, an imperfect ability to observe those quality differentials, and different information regarding quality differentials. Such is the situation regarding legal claims to future property, otherwise known as financial instruments or securities. Fraud increases the informational asymmetry and cannot only cause the market to function poorly, it can cause the market to cease to exist altogether. Regulation to prohibit fraud can restore some beauty to the market if well-designed and enforced.

Historically, regulators adopted a philosophy of policing fraud and requiring honesty and integrity to promote confidence in the market. The concept of full and fair disclosure has served the market well. When the federal securities laws were originally established, the idea of paternalistic merit regulation was considered and rejected, with good reason. $^{278}$

A regime in which private actions against all participants are available to redress fraud will cure this massive fraud problem.

273. See Klock, Mainstream Economics, supra note 114, at 331 ("When confidence is promoted ... outsiders will invest more heavily in the market. This lowers the cost of capital to business, increases aggregate investment, and improves overall economic welfare." (citation omitted)).

274. See Andreas M. Fleckner, Stock Exchanges at the Crossroads, 74 Fordham L. ReV. 2541, 2592 (2006) ("Without well-organized and efficient markets, companies will have difficulties finding capital to finance their business, which would raise capital costs and impede the entire economy.").

275. See supra notes 265 and 266 and accompanying text.

276. See, e.g., MISHKIN \& EAKINS, supra note 173, at 19 ("Well-functioning financial markets also directly improve the well-being of consumers.... Financial markets that are operating efficiently improve the economic welfare of everyone in the society.").

277. See Bernard S. Black, The Legal and Institutional Preconditions for Strong Securities Markets, 48 UCLA L. REV. 781, 786-87 (2001) (explaining how weak investor protection discourages honest firms from selling securities).

278. Klock, Fortune Tellers, supra note 19, at 76-77 (citations omitted). 


\section{CONCLUSION}

A significant factor in creating the present financial and economic crisis was fraud in the subprime mortgage industry, which spilled over into the broad financial sector and then the entire economy. ${ }^{279}$ We have also witnessed spectacular financial scandals such as Enron. Even after the enactment of regulatory reforms we learn about massive and widespread Ponzi schemes perpetrated in our markets. ${ }^{280}$ Prestigious names among giants such as Arthur Andersen and Merrill Lynch have been revealed to routinely engage in unethical business practices for short term gain rather than protect their reputation and future earnings potential. ${ }^{281}$ Now more than any time during the past seventy years we need to act to shore up our market confidence.

At one time, a relatively small segment of the public invested in publicly-traded securities. Now a significant proportion of the U.S. population owns publicly-traded stocks, either directly or indirectly. ${ }^{282} \mathrm{~A}$ major trend in the investment world has been the remarkable growth of stock ownership through defined-contribution retirement plans. ${ }^{283}$ Additionally, there has been even more remarkable growth in mutual funds. ${ }^{284}$ These trends make the direct importance of the financial markets to the majority of the U.S. public obvious.

However, there are also less obvious reasons why the financial markets are critically important, even to those who have no wealth tied to the level of the market. A simple summary of the immediate effects is that financial markets affect the cost of raising capital, which in turn affects the profitability and level of investment, which in turn affects employment, output, and income. ${ }^{285}$ Poorly functioning financial markets will lead to a high cost of capital which in turn causes otherwise

279. See Haya El Nasser and Paul Overberg, Some Parts of U.S. Escape Housing Mess; Mostly Mortgage-Free Areas See Less Dramatic Downturn, USA TodAy, Nov. 21, 2008, at A8 ("Amid a subprime mortgage meltdown that triggered a global financial crisis ....").

280. See Zachary A. Goldfarb, SEC Alleges $\$ 8$ Billion Savings Fraud; Allen Stanford, Colleagues Lied About Investments, CD Return Rates, Agency Says, WASH. Post, Feb. 18, 2009, at D1 (citing two large scandals: a $\$ 50$ billion Ponzi scheme orchestrated by Bernard Madoff, and a "massive, ongoing fraud" involving $\$ 8$ billon worth of certificates of deposits conducted by Allen Stanford).

281. See supra note 175 .

282. ChARLES P. JONES, INVESTMENTS: ANALYSIS AND MANAGEMENT 51 (8th ed. 2002).

283. Charles J. Corrado \& Bradford D. Jordan, Fundamentals Of Investments: VALUATION AND MANAGEMENT 108 (3d ed. 2005).

284. Id.; William F. SHARPE ET AL., INVESTMENTS 4 (6th ed. 1999).

285. Klock, Mainstream Economics, supra note 114, at 331. 
profitable opportunities for investments to become unprofitable. ${ }^{286}$ Alternatively, well functioning markets lead to minimal costs in raising capital, which promotes greater levels of investment and its accompanying economic benefits. ${ }^{287}$ "Prosperity provides the engine by which limited possibilities are expanded." 288

The economic benefits of well-functioning financial markets are obvious. ${ }^{289}$ Investors and businesses are able to overcome the credit risk associated with lending to strangers at the most minimal level of transactional costs thereby promoting saving and investment. ${ }^{290}$ Low capital costs result in a growing and vibrant economy with jobs and opportunity for all. But the financial markets cannot flourish if investors are not protected from fraud. ${ }^{291}$ The fraud alleged against the vendors and customers of Scientific-Atlantic was particularly egregious and clearly something that the investing public should be protected against with more than a casual caveat emptor. The remedy is simple-provide a private cause of action for aiding and abetting violations of $\S 10(\mathrm{~b})$. Such regulation provides market-based incentives for ethical conduct rather than ineffective micro-regulations. This case should result in a renewed call by members of the securities bar to lobby for civil liability in private actions in securities cases and overturn the disastrous result in Stoneridge with new legislation removing judicially created doctrines that immunize aiding and abetting securities fraud. ${ }^{292}$

A barring of secondary liability would be a rejection of longrecognized principles and would produce, contrary to the purpose of the federal securities laws, investor protections that in many cases would be less than existed at common law. The statutory controlling person provisions were not intended to preclude other forms of secondary

286. See generally MISHKIN \& EAKINS, supra note 173, at 24-29 (explaining the role financial intermediaries play in reducing costs and promoting full economic potential).

287. See id. at 238 ("[T] he availability of efficiently functioning capital markets is crucial to the continued health of the business sector.").

288. Klock, Fortune Tellers, supra note 19, at 76.

289. See generally MISHKIN \& EAKINS, supra note 173, at 18-19 (explaining the essential function of financial markets in the economy).

290. See WeLCH, supra note 87, at 898-900 (explaining how the design of corporate control rights enables investors and entrepreneurs to form an alliance).

291. Robert Cooter, Innovation, Information, and the Poverty of Nations, 33 FLA. ST. U.L. REV. 373, 386 (2005) ("The stock market cannot flourish in most poor countries because ineffective corporate and securities laws provide insufficient protection against manipulation of noncontrolling investors."); Frank B. Cross, Law and Economic Growth, 80 TEX. L. REV. 1737, 1770 (2002) ("It seems clear that government regulation of securities fraud is conducive to the development of stock markets and the associated benefit of economic growth.").

292. See Levin, supra note 29 ("Legislation reversing Stoneridge would restore civil liability for aiders and abettors of corporate fraud."). 
liability, but were intended to provide an additional basis of liability to control misconduct that otherwise might not be covered.

It has been fifteen years since Central Bank. Stoneridge has worsened the problem at an inopportune time in economic history. It is time for Congress to take back our financial markets and restore integrity and confidence.

293. Kuehnle, supra note 30, at 376. 